\title{
Improved simulation of tropospheric ozone by a global-multi-regional two-way coupling model system
}

\author{
Yingying Yan $^{1}$, Jintai Lin ${ }^{1}$, Jinxuan Chen ${ }^{1}$, and $\mathrm{Lu} \mathrm{Hu}^{2}$ \\ ${ }^{1}$ Laboratory for Climate and Ocean-Atmosphere Studies, Department of Atmospheric and \\ Oceanic Sciences, School of Physics, Peking University, Beijing 100871, China \\ ${ }^{2}$ School of Engineering and Applied Sciences, Harvard University, Cambridge, MA 02138, USA \\ Correspondence to: Jintai Lin (linjt@pku.edu.cn)
}

Received: 13 August 2015 - Published in Atmos. Chem. Phys. Discuss.: 23 September 2015

Revised: 13 January 2016 - Accepted: 11 February 2016 - Published: 29 February 2016

\begin{abstract}
Small-scale nonlinear chemical and physical processes over pollution source regions affect the tropospheric ozone $\left(\mathrm{O}_{3}\right)$, but these processes are not captured by current global chemical transport models (CTMs) and chemistryclimate models that are limited by coarse horizontal resolutions (100-500 km, typically $200 \mathrm{~km})$. These models tend to contain large (and mostly positive) tropospheric $\mathrm{O}_{3}$ biases in the Northern Hemisphere. Here we use the recently built two-way coupling system of the GEOS-Chem CTM to simulate the regional and global tropospheric $\mathrm{O}_{3}$ in 2009. The system couples the global model (at $2.5^{\circ}$ long. $\times 2^{\circ}$ lat.) and its three nested models (at $0.667^{\circ}$ long. $\times 0.5^{\circ}$ lat.) covering Asia, North America and Europe, respectively. Specifically, the nested models take lateral boundary conditions (LBCs) from the global model, better capture small-scale processes and feed back to modify the global model simulation within the nested domains, with a subsequent effect on their LBCs.

Compared to the global model alone, the two-way coupled system better simulates the tropospheric $\mathrm{O}_{3}$ both within and outside the nested domains, as found by evaluation against a suite of ground (1420 sites from the World Data Centre for Greenhouse Gases (WDCGG), the United States National Oceanic and Atmospheric Administration (NOAA) Earth System Research Laboratory Global Monitoring Division (GMD), the Chemical Coordination Centre of European Monitoring and Evaluation Programme (EMEP), and the United States Environmental Protection Agency Air Quality System (AQS)), aircraft (the High-performance Instrumented Airborne Platform for Environmental Research (HIAPER) Pole-to-Pole Observations (HIPPO) and Measurement of Ozone and Water Vapor by Airbus In- Service Air-
\end{abstract}

craft (MOZAIC)) and satellite measurements (two Ozone Monitoring Instrument (OMI) products). The two-way coupled simulation enhances the correlation in day-to-day variation of afternoon mean surface $\mathrm{O}_{3}$ with the ground measurements from 0.53 to 0.68 , and it reduces the mean model bias from 10.8 to $6.7 \mathrm{ppb}$. Regionally, the coupled system reduces the bias by $4.6 \mathrm{ppb}$ over Europe, $3.9 \mathrm{ppb}$ over North America and $3.1 \mathrm{ppb}$ over other regions. The two-way coupling brings $\mathrm{O}_{3}$ vertical profiles much closer to the HIPPO (for remote areas) and MOZAIC (for polluted regions) data, reducing the tropospheric $(0-9 \mathrm{~km})$ mean bias by $3-10 \mathrm{ppb}$ at most MOZAIC sites and by $5.3 \mathrm{ppb}$ for HIPPO profiles. The twoway coupled simulation also reduces the global tropospheric column ozone by $3.0 \mathrm{DU}$ (9.5\%, annual mean), bringing them closer to the OMI data in all seasons. Additionally, the two-way coupled simulation also reduces the global tropospheric mean hydroxyl radical by $5 \%$ with improved estimates of methyl chloroform and methane lifetimes. Simulation improvements are more significant in the Northern Hemisphere, and are mainly driven by improved representation of spatial inhomogeneity in chemistry/emissions.

Within the nested domains, the two-way coupled simulation reduces surface ozone biases relative to typical GEOSChem one-way nested simulations, due to much improved LBCs. The bias reduction is $1-7$ times the bias reduction from the global to the one-way nested simulation. Improving model representations of small-scale processes is important for understanding the global and regional tropospheric chemistry. 


\section{Introduction}

Tropospheric ozone $\left(\mathrm{O}_{3}\right)$ is a critical pollutant and the primary source of the hydroxyl radical $(\mathrm{OH}$; the dominant atmospheric oxidant). Tropospheric ozone comes from stratosphere-troposphere exchange (STE) and photochemical production, and is destroyed by chemical loss and dry deposition to the ground. Current global chemical transport models (CTMs) and chemistry-climate models simulate the spatiotemporal variations of ozone and its precursors, facilitating a global-scale source attribution analysis to improve mitigation strategies (Lin et al., 2014; HTAP, 2010; Monks et al., 2015). However, most global models are limited by coarse horizontal resolutions $(100-500 \mathrm{~km}$, typically $200 \mathrm{~km}$ ), and they cannot resolve the fine-scale processes controlling the formation, transport and removal of ozone and its precursors. Many of these models tend to overestimate the tropospheric ozone in the Northern Hemisphere (Lin et al., 2008; Stevenson et al., 2006; Fiore et al., 2009; Reidmiller et al., 2009; Young et al., 2013; Parrish et al., 2014). Previous studies have suggested various sources of model biases in emissions, chemical mechanisms, meteorological inputs and model resolutions (Wild and Prather, 2006; Lin et al., 2008; Weaver et al., 2009; J.-T. Lin et al., 2012; Doherty et al., 2013; Parrish et al., 2014; Fiore et al., 2014; Fu et al., 2015; Monks et al., 2015). Lack of capability in representing small-scale processes not resolved by the coarse-resolution global models may be an important factor for model biases, whereas the quantitative effect is much less clear, especially for the global effect of processes at scales below $100 \mathrm{~km}$.

The coarse global models underrepresent many resolutiondependent processes. Ozone simulations greatly depend on horizontal resolutions due to their nonlinear dependence on concentrations of nitrogen oxides $\left(\mathrm{NO}_{x}=\mathrm{NO}+\mathrm{NO}_{2}\right)$ and non-methane volatile organic compounds (NMVOCs) (Sillman et al., 1990). Natural (biogenic and lightning) emissions are often calculated online by the models driven by resolution-specific meteorological conditions. Coarseresolution global models cannot resolve the strong chemical and emission contrasts between urban and surrounding areas (Wild and Prather, 2006; Yan et al., 2014). In particular, the ozone chemistry is mostly $\mathrm{NO}_{x}$ saturated (or volatile organic compound (VOC)-limited) in the urban areas but $\mathrm{NO}_{x}$ limited in the surrounding rural regions, but the contrast is not resolved by the global model by assuming a fully mixed grid box with no sub-grid variability. Vertical transport is also resolution dependent and not well resolved by global models by smoothing out the nearby upward and downward motions. Chen et al. (2009) showed that the global GEOS-Chem (at a $\sim 200 \mathrm{~km}$ resolution) poorly represents the terrain-related circulation around the Tibetan Plateau as the topographical feature is smoothed out. M. Lin et al. (2012a) showed that the simulated Asian influence to the US ozone is stronger with an increase in model resolution.
Several global high-resolution simulations have been conducted in part to enhance the representation of small-scale processes (M. Lin et al., 2012a, b; Emmons et al., 2010). For example, M. Lin et al. (2012a) used the Geophysical Fluid Dynamics Laboratory Atmospheric Model version 3 (GFDL AM3) model (at $\sim 50 \mathrm{~km}$ resolution) to simulate the Asian pollution influence for the US in May-June 2010; the highresolution simulation was performed for 6 months. Emmons et al. (2010) used the MOZART-4 simulation (at $\sim 70 \mathrm{~km}$ ) to simulate Mexican air quality in March 2006. A global highresolution simulation is often prohibitive due to much enhanced computational and data requirements. This is particularly true for a relatively long simulation (1 year or more) that is necessary to quantify the effect of small-scale processes in different seasons and to allow for a high-resolution model spin-up period. Many high-resolution regional models have also been developed that better simulate the smallscale processes in the targeted domains (e.g., Huang et al., 2008; Lin et al., 2010; Huang et al., 2010). Most of these regional models take the lateral boundary conditions (LBCs) of chemicals from a coarse-resolution global model without affecting the global model simulation, i.e., a typical "one-way" nesting setup. Thus, the improved representation of smallscale processes within the regional domain does not affect the global large-scale chemical background (simulated by the global model) that would otherwise have additional effects on the LBCs of regional models. Our previous study on carbon monoxide (CO) demonstrated that accounting for these feedback processes enhances the simulated $\mathrm{CO}$ concentrations both within and outside the regional model domains, with a global average enhancement of $10 \%$ (equivalent to a $25 \%$ increase in global CO emissions) (Yan et al., 2014).

This study aims to address how the small-scale processes over the pollution source regions (not resolved by a typical global model at a $\sim 200 \mathrm{~km}$ resolution) affect the tropospheric $\mathrm{O}_{3}$ in the global domain, both inside and outside the source regions. For this purpose, we contrast the global tropospheric $\mathrm{O}_{3}$ in 2009 simulated by a coarseresolution global GEOS-Chem model (at $2.5^{\circ}$ long. $\times 2^{\circ}$ lat.) against the simulation by a recently built GEOS-Chembased global-multi-regional two-way coupling system (Yan et al., 2014). The system uses the PeKing University CouPLer (PKUCPL) to integrate the global GEOS-Chem model (at $2.5^{\circ}$ long. $\times 2^{\circ}$ lat.) and its three nested models (at $0.667^{\circ}$ long. $\times 0.5^{\circ}$ lat.) covering the major pollution source regions of Asia (Chen et al., 2009), North America (Zhang et al., 2011) and Europe (Vinken et al., 2014), respectively. See Fig. 1 for a visualized model domain definition. In particular, the nested models provide results to modify the global model simulation within respective nested domains, while taking the LBCs from the global model. The highresolution nested models better resolve atmospheric processes at scales smaller than $200 \mathrm{~km}$ over these pollution source regions, and the "two-way" coupling allows for the improvements to have a global impact, i.e., via feedbacks 


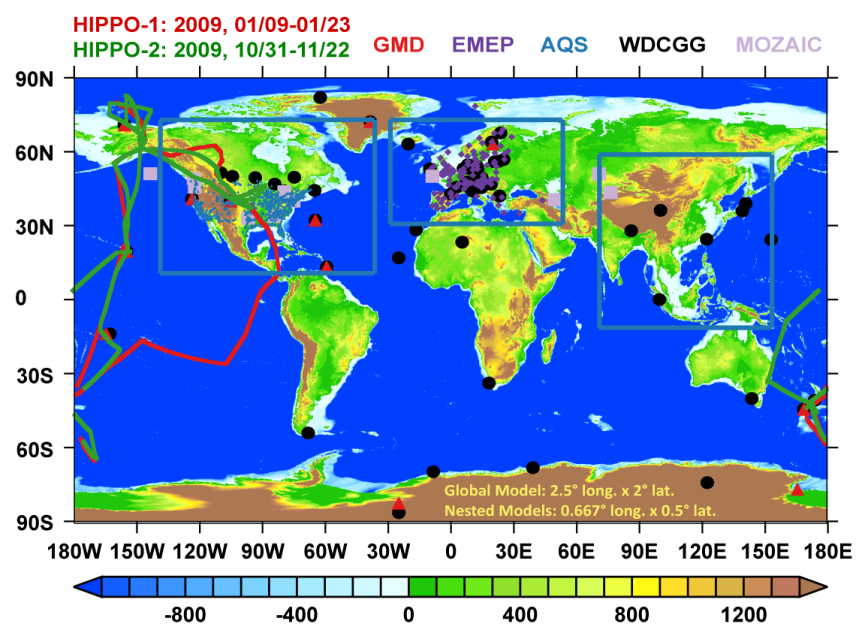

Figure 1. Dark green squares bounding the domains of three nested models covering Asia $\left(70-150^{\circ} \mathrm{E}, 11-55^{\circ} \mathrm{N}\right)$, North America $\left(140-40^{\circ} \mathrm{W}, 10-70^{\circ} \mathrm{N}\right)$ and Europe $\left(30^{\circ} \mathrm{W}-50^{\circ} \mathrm{E}, 30-70^{\circ} \mathrm{E}\right)$. Also shown are sites of ground-level ozone measurements from WDCGG (black circle), GMD (red triangle), AQS (blue triangle) and EMEP (purple diamond); airports in the MOZAIC program for the tropospheric ozone profiles (pink square); and aircraft flight tracks in the HIPPO campaigns (red line for HIPPO-1, and green line for HIPPO-2). The overlaid map is the surface elevation (m) from a 2 min Gridded Global Relief Data (ETOPO2v2) available at NGDC Marine Trackline Geophysical database (http://www.ngdc. noaa.gov/mgg/global/etopo2.html).

between the global and nested regional models. Note that our nested model resolution is still relatively coarse compared to some other regional model studies (e.g., Huang et al., 2008; Lin et al., 2009; Kuhlmann et al., 2015; Terrenoire et al., 2015); our future studies will take advantage of the new generation GEOS-Chem nested models at $0.3125^{\circ}$ long. $\times 0.25^{\circ}$ lat. to capture smaller-scale processes not resolved on a $0.667^{\circ}$ long. $\times 0.5^{\circ}$ lat. grid.

Simulations by the coupled system and the global model alone are evaluated against a suite of ozone measurements within and outside the nested model domains from the World Data Centre for Greenhouse Gases (WDCGG), the United States National Oceanic and Atmospheric Administration (NOAA) Earth System Research Laboratory Global Monitoring Division (GMD), the Chemical Coordination Centre of European Monitoring and Evaluation Programme (EMEP), the United States Environmental Protection Agency Air Quality System (AQS), the airborne measurements from High-performance Instrumented Airborne Platform for Environmental Research (HIAPER) Pole-to-Pole Observations (HIPPO) campaigns, the Measurement of Ozone and Water Vapor by Airbus In- Service Aircraft (MOZAIC) aircraft program and two satellite products retrieved from the Ozone Monitoring Instrument (OMI). Surface ozone simulations are compared between the two-way system and a traditional one- way nesting setup. Model evaluation reveals important simulation improvements via the two-way coupling.

The rest of the paper is organized as follows. Section 2 describes the two-way coupled model system. Section 3 presents the ground, aircraft and OMI measurements. Section 4 compares the tropospheric budgets of ozone and related species between the coupled system and the global CTM alone. The section also delineates the individual effects of various chemical and non-chemical factors affecting the simulated ozone differences. Section 5 compares the simulated tropospheric ozone with measurements, focusing on daily, seasonal and vertical variability of ozone to demonstrate the superiority of the coupled system over the global model alone and a traditional one-way nesting setup. Section 6 concludes the present study.

\section{Two-way coupled GEOS-Chem model system}

The current global-multi-regional two-way coupled model system (http://wiki.seas.harvard.edu/geos-chem/index. php/Two-way_coupling_between_global_and_nested_ GEOS-Chem_models) is built on version 9-02 of GEOSChem. In this system, both the global and three nested CTMs are driven by the GEOS-5 assimilated meteorological fields from the National Aeronautic and Space Administration (NASA) Global Modeling and Assimilation Office (GMAO). The GEOS-5 data on the native $0.667^{\circ}$ long. $\times 0.5^{\circ}$ lat. grid are used directly to drive the nested models. To drive the global model, the meteorological data are regridded to a reduced resolution at $2.5^{\circ}$ long. $\times 2^{\circ}$ lat. All models have 47 vertical layers, with about 10 layers of $\sim 0.13 \mathrm{~km}$ thickness below $850 \mathrm{hPa}$.

In the coupling system, all global and nested models are run with the full $\mathrm{O}_{x}-\mathrm{NO}_{x}-\mathrm{VOC}-\mathrm{CO}-\mathrm{HO}_{x}$ gaseous chemistry (Mao et al., 2013), the Linoz stratospheric ozone scheme (McLinden et al., 2000), and online aerosol calculations. Based on J.-T. Lin et al. (2012), we have modified the chemical mechanism as follows. The reaction constants for $\mathrm{OH}+\mathrm{NO}_{2}$ follow Mollner et al. (2010) for low- and high-pressure limits, i.e., $k_{0}=1.48 \times$ $10^{-30} \times(T / 300)^{-3} \mathrm{~cm}^{6}$ molecule ${ }^{-2} \mathrm{~s}^{-1}$, and $k_{\text {inf }}=2.58 \times$ $10^{-11} \mathrm{~cm}^{3}$ molecule ${ }^{-1} \mathrm{~s}^{-1}$. Aerosol uptake of the hydroperoxyl radical $\left(\mathrm{HO}_{2}\right)$ accounts for its self-reaction in aqueous particles (Thornton et al., 2008). Over the continental boundary layer, the uptake rate is fixed at 0.07 to account for catalysis by transition metal ions (TMIs) (Thornton et al., 2008). Over China, however, the $\mathrm{HO}_{2}$ uptake rate is assumed to be at least 0.2 to account for the much higher fraction of TMIs in Chinese aerosols (J.-T. Lin et al., 2012); the large uptake rate is supported by recent observations (Taketani et al., 2012). The uptake of nitrogen pentoxide $\left(\mathrm{N}_{2} \mathrm{O}_{5}\right)$ on aerosols follows the Evans and Jacob (2005) parameterization, but the uptake rate is reduced by 10 times based on more recent estimates (Bertram et al., 2009). Vertical mixing in the planetary 
boundary layer (PBL) employs a non-local scheme (Holtslag and Boville, 1993; Lin and McElroy, 2010). Model convection adopts the relaxed Arakawa-Schubert scheme (Rienecker et al., 2008).

We use the Linoz stratospheric ozone scheme (McLinden et al., 2000) that produces the stratospheric ozone with reasonable stratosphere-troposphere exchange (STE) of ozone on an annual basis (Zhang et al., 2014). A model with a full stratospheric chemistry (e.g., M. Lin et al., 2012b; Eastham et al., 2014) would better simulate the variability of stratospheric ozone and its STE. This variability is particularly important for understanding the episodic ozone events (M. Lin et al., 2012b, 2015). Nevertheless, here we aim to evaluate the effect of small-scale processes within the troposphere on the general annual and spatial pattern of tropospheric ozone. Thus, a simulation with detailed stratospheric chemistry is outside the scope of this study. Also, for the STE of ozone within the nested domains, we adjust the nested model simulations to approximate the global model results by halving the Linoz ozone production rate in the stratosphere, as we focus on the processes that affect the tropospheric ozone. This adjustment does not affect the tropospheric radiation influx, which is constrained by monthly Total Ozone Mapping Spectrometer Solar Backscattered UltraViolet (TOMS/SBUV) ozone data (http://acdb-ext.gsfc.nasa. gov/Data_services/merged/).

The two-way coupling system employs the PKUCPL coupler to integrate all models. Yan et al. (2014) presented a detailed description and evaluation of the coupling mechanism. Briefly, the coupler takes global model results for all chemical concentrations to update the LBCs of nested models. The coupler simultaneously replaces global model results in the troposphere within the nested domains by nested model results, after a mass-conserved area-weighted grid conversion procedure. The model information is exchanged every $3 \mathrm{~h}$; a higher exchange frequency at $1 \mathrm{~h}$ leads to similar results. All model simulations proceed in parallel under the two-way coupling framework. The chemistry time step is 30 min in the global model and $20 \mathrm{~min}$ in the nested models; and the transport time step is half of the chemistry time step for all models. Chemical and transport processes are simulated in sequence: transport + chemistry + transport, transport + chemistry + transport, etc.

For our focused analysis in 2009, both the two-way coupled system and the global model alone are run from July 2008 to December 2009, allowing for a 6-month spin-up period in 2008. Initial conditions of chemicals are regridded from a simulation at $5^{\circ}$ long. $\times 4^{\circ}$ lat. conducted from 2005 . All models in the two-way coupling framework proceed in parallel with eight-core (Intel(R) Xeon(R) CPU X7550 at $2.00 \mathrm{GHz}$ ) OpenMP parallelization for each model; a total of 32 cores are used for the coupled system and eight for the global model alone. The wall-clock time of the coupled system is slightly higher (by $<2 \%$ ) than that of the slowest model, the North American nested model, due to some overhead for data exchange. On this relatively old and slow computer, it takes about 15 days for the coupled system to finish 1 simulation year.

\section{Model emissions}

Table 1 summarizes the prescribed anthropogenic and biomass burning emissions. Global anthropogenic emissions are taken from the Emission Database for Global Atmospheric Research (EDGAR) v4.2 inventory for $\mathrm{CO}$ and $\mathrm{NO}_{x}$. Anthropogenic emissions of NMVOCs use as default the REanalysis of the TROpospheric chemical composition (RETRO) monthly global inventory for 2000 , as implemented by Hu et al. (2015). These global inventories are further replaced by regional inventories over Asia, North America and Europe. Emission data include monthly or seasonal variability.

Monthly biomass burning emissions are taken from the Global Fire Emissions Database version 3 (GFED3) (van der Werf et al., 2010). Other natural emissions (lightning $\mathrm{NO}_{x}$, soil $\mathrm{NO}_{x}$, and biogenic NMVOCs) are parameterized and calculated on-the-fly based on model meteorology; these emissions are thus resolution dependent. Soil $\mathrm{NO}_{x}$ emissions follow Hudman et al. (2012). Lightning $\mathrm{NO}_{x}$ emissions follow the Price and Rind scheme with a further satellitebased adjustment and a backward "C-shape" vertical profile (Price and Rind, 1992; Ott et al., 2010; Murray et al., 2012). Biogenic NMVOC emissions are calculated with the MEGAN v2.1 (PECCA) model (Guenther et al., 2012) driven by monthly mean MODIS leaf area index data.

Table 2 shows slight differences in global total emissions of ozone precursors $\left(\mathrm{CO}, \mathrm{NO}_{x}\right.$, and NMVOCs) between the global model alone and the two-way coupled system. In the coupled system, global emissions from all sources are about $878 \mathrm{Tg} \mathrm{yr}^{-1}$ for $\mathrm{CO}, 45.5 \mathrm{Tg} \mathrm{N} \mathrm{yr}^{-1}$ for $\mathrm{NO}_{x}$ and $723 \mathrm{Tg} \mathrm{Cyr}^{-1}$ for NMVOCs. These values are larger than those in the global model by about $0.9,0.7$ and $6.5 \%$, respectively. Greater emission differences are found for biogenic NMVOCs (by $6.9 \%$ ) and fertilizer soil $\mathrm{NO}_{x}$ (by $25.4 \%$ ), reflecting strong resolution dependence.

Figure 2 shows the spatial distributions of annual NMVOCs and $\mathrm{NO}_{x}$ emissions in the nested models (first and third columns) and the global model (second and fourth columns). The nested and global models exhibit similar spatial patterns for NMVOCs emissions. Summed over a given nested domain, the nested models have higher emissions of NMVOCs than the global model by $16-48 \%$, mainly a result of stronger isoprene emissions. The spatial patterns of $\mathrm{NO}_{x}$ emissions differ greatly between the nested and global models, with local emission spikes much more obvious in the nested models, although the regional totals are similar (within 5\%).

The differences in model representation of $\mathrm{NO}_{x}$ and NMVOCs emissions affect the simulated ozone chemistry. The difference in regional emission magnitude (mainly for 
Table 1. Anthropogenic and biomass burning emission inventories used by GEOS-Chem.

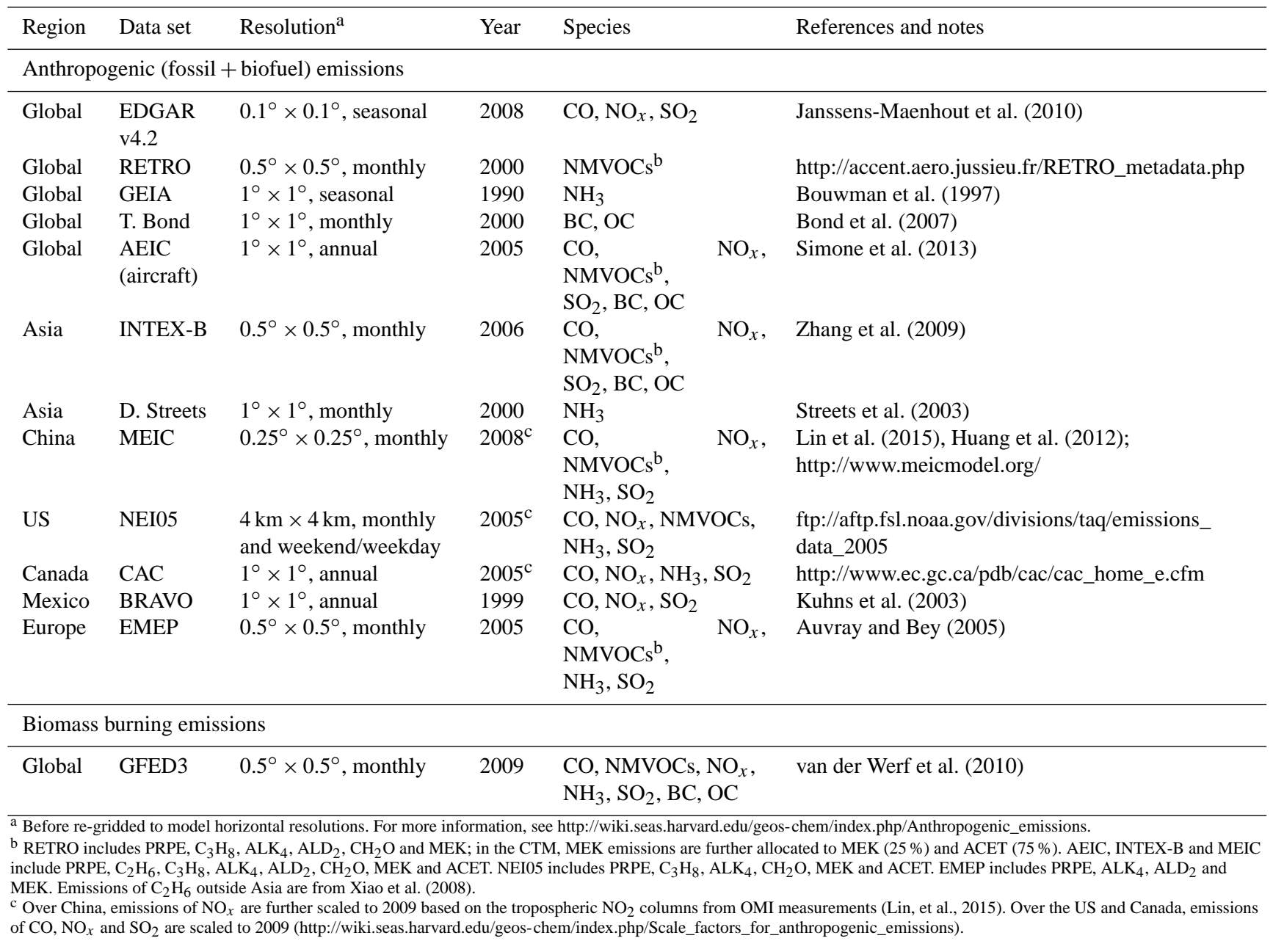

Table 2. Global emissions of CO, $\mathrm{NO}_{x}$ and NMVOCs in GEOS-Chem for 2009.

\begin{tabular}{lrrr}
\hline Total emissions $^{\mathrm{a}}$ & Global model & Two-way model & Percentage difference \\
\hline CO emissions (Tg) & 869.9 & 877.8 & $0.9 \%$ \\
Fossil + biofuel & 500.5 & 504.3 & $0.8 \%$ \\
Biomass burning & 327.6 & 327.3 & $-0.1 \%$ \\
$\mathrm{NO}_{x}$ emissions (TgN) & 45.2 & 45.5 & $0.7 \%$ \\
Fossil + biofuel & 27.5 & 27.5 & 0 \\
Lightning & 6.08 & 6.18 & $1.7 \%$ \\
Natural soil & 5.81 & 5.86 & $0.9 \%$ \\
Fertilizer soil & 0.71 & 0.89 & $25.4 \%$ \\
Biomass burning & 4.55 & 4.54 & $-0.2 \%$ \\
Aircraft & 0.51 & 0.51 & 0 \\
NMVOCs emissions (TgC) & 678.4 & 722.7 & $6.5 \%$ \\
Fossil + biofuel & 27.8 & 28.1 & $1.1 \%$ \\
Biogenic NMVOCs & 640 & 684 & $6.9 \%$ \\
Biomass burning & 10.6 & 10.6 & 0 \\
\hline
\end{tabular}

a Slight differences may exist between the two model frameworks in the prescribed anthropogenic (fossil + biofuel) and biomass burning emissions, as a result of the combination of and regridding from various inventories. The consequent impacts on model simulations are negligible.

${ }^{\mathrm{b}}$ Emitted NMVOCs include ISOP, PRPE, $\mathrm{C}_{3} \mathrm{H}_{8}, \mathrm{ALK}_{4}, \mathrm{C}_{2} \mathrm{H}_{6}, \mathrm{ALD}_{2}, \mathrm{CH}_{2} \mathrm{O}$, ACET and MEK. 


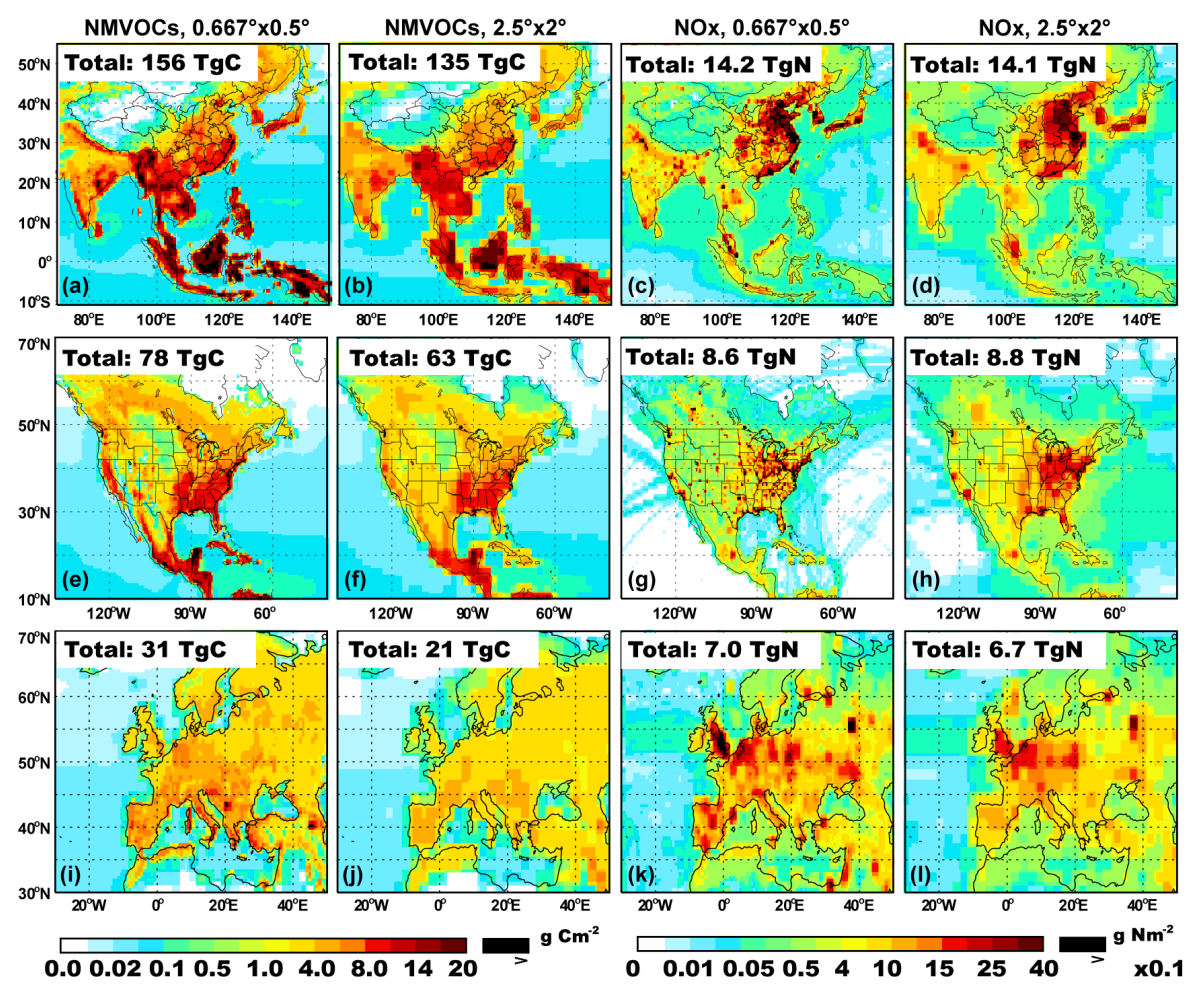

Figure 2. Total (anthropogenic + natural) emissions of NMVOCs and $\mathrm{NO}_{x}$ over Asia, North America and Europe in 2009, as represented in the nested models $\left(0.667^{\circ} \times 0.5^{\circ}\right)$ and the global model $\left(2.5^{\circ} \times 2^{\circ}\right)$. Values outside the upper bound of color intervals are shown in black. Color intervals are nonlinear to better present the data range; an interval without labeling represents the mean of adjacent two intervals. Also depicted in each panel is the regional total.

biogenic NMVOC in summer) affects the surface ozone simulation within the nested domains (Sect. 5.1), but with a marginal effect on the global tropospheric ozone as a whole (Sect. 4.3). The better resolved emission spatial variability, as well as associated chemical contrast by the nested models, greatly affects both the surface (Sect. 5.1) and the tropospheric ozone (Sect. 4.3, 5.2, and 5.3).

\section{Ground, aircraft and OMI measurements}

\subsection{Ground measurements from WDCGG, GMD, EMEP and AQS}

We employ four measurement networks to evaluate the modeled ground-level ozone mixing ratios in 2009. As shown in Fig. 1, these networks contain hourly ozone measurements from a total of 1420 urban, suburban or remote sites from WDCGG (64 sites, http://ds.data. jma.go.jp/gmd/wdcgg/cgi-bin/wdcgg/catalogue.cgi), GMD (12 sites, http://www.esrl.noaa.gov/gmd/), EMEP (130 sites, http://www.nilu.no/projects/ccc/emepdata.html) and AQS (1214 sites, http://aqsdr1.epa.gov/aqsweb/aqstmp/airdata/ download_files.html). For model evaluation, we derive the afternoon (12:00-18:00 LT, local time) mean ozone mixing ratios from the hourly data. Modeled afternoon ozone is sampled from the lowest layer (centered at $\sim 0.065 \mathrm{~km}$ ) in grid cells covering the ground sites, and are sampled from the hourly outputs coincident with available measurements. The afternoon mean ozone is close to the maximum $8 \mathrm{~h}$ average ozone in both measurements (36.1 vs. $39.3 \mathrm{ppb}$ averaged over the 1420 sites) and model simulations ( 46.8 vs. $48.4 \mathrm{ppb}$ for the global model alone; 42.6 vs. $44.5 \mathrm{ppb}$ for the two-way coupled system). Models also capture the diurnal cycle of measured ozone fairly well, although with positive biases in both daytime and nighttime (not shown), consistent with our previous work (Lin and McElroy, 2010).

\subsection{Aircraft measurements from MOZAIC and HIPPO}

We take ozone vertical profiles in 2009 at 11 sites of the MOZAIC program (pink squares in Fig. 1; data available at http://www.iagos.fr/web/) to evaluate the modeled vertical and seasonal distributions of tropospheric ozone. Located in major cities, these sites are representative of the polluted environment. Since 1994, the MOZAIC program has employed five commercial aircrafts to measure ozone concentrations throughout the troposphere and lower stratosphere (Marenco et al., 1998). Ozone is measured with an accuracy estimated at $\pm(2 \mathrm{ppbv}+2 \%)$ and a $4 \mathrm{~s} \mathrm{time} \mathrm{response}(<50 \mathrm{~m}$ 
vertical resolution) (Thouret et al., 1998). We use measurements taken during both takeoff and landing of the aircrafts to represent the vertical profiles over the associated airports (Zbinden et al., 2013). Each of the 11 sites chosen here has at least 40 profiles in 2009. Measurements are available from the ground level $(0.075 \mathrm{~km})$ to the upper troposphere and lower stratosphere (UTLS) at $0.15 \mathrm{~km}$ intervals. Model results are sampled at times and locations consistent with the measurements.

For model evaluation in the remote areas, we use 282 ozone vertical profiles over the Pacific Ocean from two HIPPO (HIPPO-1 and HIPPO-2) aircraft campaigns conducted in 2009. The HIPPO campaigns were conducted in the remote troposphere over the Pacific, Arctic and nearAntarctic regions to facilitate atmospheric chemistry analysis (Wofsy, 2011). During HIPPO, ozone was measured by the $\mathrm{NOAA} \mathrm{O}_{3}$ photometer using direct absorption at $254 \mathrm{~nm}$ (Proffitt and McLaughlin, 1983; Kort et al., 2012). We use the merged data set that has a vertical resolution of $0.1 \mathrm{~km}$ (data available at http://hippo.ornl.gov/data_access/). To ensure spatiotemporal consistency with the HIPPO data, model ozone is sampled at the times and locations of the measurements.

\subsection{Two OMI products for tropospheric column ozone}

We use two monthly OMI tropospheric column ozone (TCO) products that have been used to study the tropospheric ozone variability and sources (Ziemke et al., 2011; Kim et al., 2013). The first product is based on an optimal estimation technique by Liu et al. $(2007,2010)$ with modifications as described in Kim et al. (2013), and is referred to as $\mathrm{OMI} / \mathrm{LIU}$ hereafter. For OMI/LIU, errors for individual TCO retrievals are typically $2-5$ DU (Liu et al., 2010). Validation against ozonesonde data shows that mean OMI/LIU TCO agrees with ozonesonde data to within $2 \mathrm{DU}$ for both the tropics $\left(30^{\circ} \mathrm{S}-30^{\circ} \mathrm{N}\right)$ and northern mid-latitudes $\left(30-60^{\circ} \mathrm{N}\right)$, but with season-dependent biases, varying from $-0.8 \mathrm{DU}$ in summer (JJA) to $2.1 \mathrm{DU}$ in winter (DJF) for $30^{\circ} \mathrm{S}-30^{\circ} \mathrm{N}$, and varying from $-0.1 \mathrm{DU}$ in JJA to $3 \mathrm{DU}$ in DJF for 30 $60^{\circ} \mathrm{N}$ (X. Liu, personal communication, 2015). The second product is the OMI/Microwave Limb Sounder (MLS) data set that subtracts the OMI total column ozone by the MLS stratospheric ozone (Ziemke et al., 2011). Ziemke et al. (2011) validated the OMI/MLS data against the Southern Hemisphere Additional OZonesondes (SHADOZ) and the World Ozone and Ultraviolet radiation Data Center (WOUDC) ozonesonde measurements. They found that, on average, the monthly mean OMI/MLS tropospheric ozone mixing ratio is smaller than the ozonesonde data by about $1 \mathrm{ppb}(2 \%)$, with large seasonal dependence and a root mean square error at 6-8 ppb. For the present analysis, we average these two independent TCO data sets to reduce data uncertainties; this leads to a third data set referred to as OMI_MEAN.
We use the monthly mean OMI products for 2009 . The $\mathrm{OMI} / \mathrm{LIU}$ data set is on a $2.5^{\circ}$ long. $\times 2^{\circ}$ lat. grid. The OMI/MLS product provides data at $1.25^{\circ}$ long. $\times 1^{\circ}$ lat. from $60^{\circ} \mathrm{S}$ to $60^{\circ} \mathrm{N}$. We calculate the OMI_MEAN TCO after regridding the OMI/MLS data to match OMI/LIU. Data polarward of $60^{\circ}$ are discarded due to higher uncertainty. Modeled monthly mean TCO is calculated from all daily data at the OMI overpass time (13:00-15:00 LT) applied with the monthly mean OMI/LIU averaging kernel; daily averaging kernel data are not available, and the modeled global annual average TCO with and without applying the averaging kernel differ by $0.6 \%$. These OMI products and model simulations differ between each other in definitions of tropopause height and days of valid data, whose effects are found to be small. To examine the effect of different tropopause heights, we re-calculated in a test analysis the OMI/LIU, OMI_MEAN and model TCO by applying the OMI/MLS tropopause. The resulting bias of the global model relative to OMI_MEAN $(2.8 \mathrm{DU}, 8.9 \%)$ is similar to the bias without adjusting the tropopause (2.9 DU, 9.2\%). The differences in days of valid data also have a marginal effect, as confirmed by examining the TCO difference between OMI/MLS and global model simulation sampled from days with valid OMI/MLS data (note that the OMI/MLS product also provides daily data for such analysis). The calculated TCO difference (3.9 DU; $12.8 \%$ ) is close to the difference (4.0 DU; $13.1 \%$ ) without sampling model results.

\section{Effects of two-way coupling on simulated tropospheric budgets of ozone and related species}

This section examines the effect of two-way coupling on the simulated tropospheric ozone budget in 2009 (Sect. 4.1), with additional discussions on $\mathrm{NO}_{x}, \mathrm{CO}$, NMVOCs, $\mathrm{OH}$ and lifetimes of methane and methyl chloroform (MCF) (Sect. 4.2). In Sect. 4.3, we delineate the chemical and nonchemical factors driving the differences between the twoway system and the global model alone.

\subsection{Tropospheric ozone budget}

Table 3 contrasts the global tropospheric $\mathrm{O}_{3}$ budgets in 2009 simulated by the two-way coupled system against those by the global model alone. The chemical production and loss are calculated for the odd oxygen family $\left(\mathrm{O}_{x}=\mathrm{O}_{3}+\mathrm{O}+\mathrm{NO}_{2}+2 \mathrm{NO}_{3}+3 \mathrm{~N}_{2} \mathrm{O}_{5}+\mathrm{PANs}+\mathrm{HNO}_{3}+\right.$ $\mathrm{HNO}_{4}$ ), following $\mathrm{Wu}$ et al. (2007). The chemical production of $\mathrm{O}_{x}$ is mainly driven by reactions of NO with peroxy radicals, and the chemical loss is mostly due to the $\mathrm{O}\left({ }^{1} \mathrm{D}\right)+\mathrm{H}_{2} \mathrm{O}$ reaction and reactions of ozone with $\mathrm{OH}$ and $\mathrm{HO}_{2}$. The coupled system produces slightly higher (by $\sim 1.0 \%$ ) chemical loss and production of $\mathrm{O}_{x}$ than the global model alone. Ozone dry deposition in the coupled system $(867 \mathrm{Tg})$ is smaller by $1.7 \%$ than the global model 
Table 3. Global tropospheric budgets of ozone and related species for 2009.

\begin{tabular}{|c|c|c|c|}
\hline & Global model & Two-way model & Percentage difference \\
\hline \multicolumn{4}{|l|}{ Tropospheric budget of ozone ${ }^{a}$} \\
\hline Chemical loss of $\mathrm{O}_{x}(\mathrm{Tg})$ & 4491 & 4537 & $1.0 \%$ \\
\hline Chemical production of $\mathrm{O}_{x}(\mathrm{Tg})$ & 4885 & 4928 & $0.9 \%$ \\
\hline Dry deposition of $\mathrm{O}_{x}(\mathrm{Tg})$ & 909 & 894 & $-1.7 \%$ \\
\hline STE of $\mathrm{O}_{x}(\mathrm{Tg})^{\mathrm{b}}$ & 515 & 503 & $-2.3 \%$ \\
\hline Dry deposition of $\mathrm{O}_{3}(\mathrm{Tg})$ & 882 & 867 & $-1.7 \%$ \\
\hline STE of $\mathrm{O}_{3}(\mathrm{Tg})^{\mathrm{b}}$ & 488 & 478 & $-2.0 \%$ \\
\hline $\mathrm{O}_{3}$ burden $(\mathrm{Tg})$ & 384 & 348 & $-9.5 \%$ \\
\hline Mean TCO (DU) & 34.5 & 31.5 & $-8.7 \%$ \\
\hline $\mathrm{O}_{3}$ lifetime (days) & 26.1 & 23.5 & $-9.9 \%$ \\
\hline \multicolumn{4}{|c|}{ Tropospheric burdens and lifetimes of other species } \\
\hline $\mathrm{NO}_{x}$ burden $(\mathrm{TgN})$ & 0.169 & 0.176 & $4.1 \%$ \\
\hline NMVOCs burden $(\mathrm{TgC})^{\mathrm{c}}$ & 10.1 & 10.2 & $1.0 \%$ \\
\hline $\mathrm{CO}$ burden $(\mathrm{Tg})$ & 359 & 398 & $10.8 \%$ \\
\hline $\mathrm{OH}$ number concentration $\left(10^{6} \mathrm{~cm}^{-3}\right)$ & 1.18 & 1.12 & $-5.0 \%$ \\
\hline OH-related MCF lifetime $(y r)^{d}$ & 5.58 & 5.87 & $5.2 \%$ \\
\hline OH-related methane lifetime $(\mathrm{yr})^{\mathrm{d}}$ & 9.63 & 10.12 & $5.1 \%$ \\
\hline
\end{tabular}

${ }^{a}$ Chemical production and loss rates are calculated for the odd oxygen family $\left(\mathrm{O}_{x}=\mathrm{O}_{3}+\mathrm{O}+\mathrm{NO}_{2}+2 \mathrm{NO}_{3}+3 \mathrm{~N}_{2} \mathrm{O}_{5}+\mathrm{PANs}+\right.$ $\mathrm{HNO}_{3}+\mathrm{HNO}_{4}$, Wu et al., 2007), to exclude recycling reactions between $\mathrm{O}_{3}$ and other $\mathrm{O}_{x}$ species. We note that $\mathrm{O}_{3}$ accounts for over $95 \%$ of the mass of $\mathrm{O}_{x}$. The tropopause is defined in GEOS-5 as at the pressure where the function $\left[0.03 T-\log _{10} P\right]$ reaches its first minimum above the surface (http://acmg.seas.harvard.edu/geos/wiki_docs/geos5/GEOS-5.2.0-File_Specification.pdf).

b Stratosphere-troposphere exchange is inferred from mass balance: $\mathrm{O}_{x} \mathrm{STE}=\mathrm{O}_{x}$ chemical loss $+\mathrm{O}_{x}$ dry deposition $-\mathrm{O}_{x}$ chemical production, and $\mathrm{O}_{3} \mathrm{STE}=\mathrm{O}_{x}$ chemical loss $+\mathrm{O}_{3}$ dry deposition $-\mathrm{O}_{x}$ chemical production.

${ }^{c}$ NMVOCs for burden calculation include the emitted species only: ISOP, PRPE, $\mathrm{C}_{3} \mathrm{H}_{8}, \mathrm{ALK}_{4}, \mathrm{C}_{2} \mathrm{H}_{6}, \mathrm{ALD}_{2}, \mathrm{CH}_{2} \mathrm{O}, \mathrm{ACET}$ and MEK.

$\mathrm{d}$ Observation-based estimates are 10.2 \pm 0.8 (Prinn et al., 2005) or 11.2 \pm 1.3 (Prather et al., 2012) years for OH-related methane

lifetime, and 6.0 \pm 0.4 (Prinn et al., 2005) or $6.3 \pm 0.4$ (Prather et al., 2012) years for OH-related MCF lifetime.

alone $(882 \mathrm{Tg})$. The STE of ozone in the coupled simulation $(478 \mathrm{Tg})$ is also lower than the global model alone $(488 \mathrm{Tg})$ by $2.0 \%$, partly compensating for the weaker deposition. This small difference in STE affects the simulated global tropospheric mean ozone by $1.1 \%$ (see Sect. 4.3).

Table 3 shows that the coupled system produces a tropospheric ozone burden at $348 \mathrm{Tg}$, about $9.5 \%$ lower than the burden simulated by the global model alone $(384 \mathrm{Tg})$. Correspondingly, the lifetime of tropospheric ozone in the coupled system (burden divided by sink $=23.5$ days) is shorter than that in the global model (26.1 days) by $9.9 \%$. The large reduction in ozone burden and lifetime, despite the small change in chemical production and loss of $\mathrm{O}_{x}$, reflects a faster chemical evolution of ozone on a per molecule basis. Although both lifetimes calculated here are broadly consistent with previous studies (19.9-25.5 days from ACCMIP, Young et al., 2013; and 17.3-25.9 days from ACCENT, Stevenson et al., 2006), the reduction due to our model coupling indicates a significant effect of small-scale processes resolved by the finer resolution, especially the fine-scale spatial variability of emissions and associated chemistry.

Table 4 shows the seasonal dependence of ozone burden and $\mathrm{O}_{x}$ chemical loss and production. The global model alone produces the largest chemical loss in the Northern Hemisphere (NH) summer $(1252 \mathrm{Tg})$ and the smallest loss in winter $(1036 \mathrm{Tg})$. The coupled model reduces the chem- ical loss by $1.2 \%$ (to $1237 \mathrm{Tg}$ ) in $\mathrm{NH}$ summer, due to a lower ozone abundance overcompensating for a higher per-molecule loss rate. In winter, the coupled model enhances the loss by $2.3 \%$ (to $1060 \mathrm{Tg}$ ), because a higher permolecule loss rate from reactions with $\mathrm{NO}_{x}$ more than offsets a lower ozone abundance. By comparison, the coupled model slightly increases the chemical production by $0.3-1.3 \%$ in all seasons.

\section{2 $\mathrm{NO}_{x}, \mathrm{CO}, \mathrm{NMVOCs}, \mathrm{OH}$, methane lifetime and MCF lifetime}

Table 3 shows that the two-way coupling also significantly affects the tropospheric burdens of ozone-related species. Burdens of NMVOCs $(10.2 \mathrm{Tg} \mathrm{C}$; see footnote of Table 3 for species included), $\mathrm{NO}_{x}(0.176 \mathrm{Tg} \mathrm{N})$ and $\mathrm{CO}(398 \mathrm{Tg})$ in 2009 are higher than those simulated by the global model alone by 1.0, 4.1 and $10.8 \%$, respectively. Table 3 also shows that the global annual mean air-mass-weighted tropospheric $\mathrm{OH}$ simulated by the two-way coupled system is lower by $5.0 \%$ than that simulated by the global model alone $(1.12$ vs. $1.18 \times 10^{6} \mathrm{~cm}^{-3}$ ). The sensitivity of $\mathrm{OH}$ to model resolution is broadly consistent with previous studies (Yan et al., 2014; Wild and Prather, 2006; Valin et al., 2011). In particular, Yan et al. (2014) showed a similar OH reduction by $4 \%$ via the two-way coupling based on an earlier version of GEOS-Chem (v8-3-02). 
Table 4. Global tropospheric ozone burden and $\mathrm{O}_{x}$ chemical production and loss in individual seasons of 2009.

\begin{tabular}{|c|c|c|c|c|c|c|c|c|c|c|c|c|}
\hline & \multicolumn{3}{|c|}{ MAM } & \multicolumn{3}{|c|}{ JJA } & \multicolumn{3}{|c|}{ SON } & \multicolumn{3}{|c|}{ DJF } \\
\hline & GB & $\mathrm{TW}$ & Diff. (\%) & GB & TW & Diff. $(\%)$ & GB & $\mathrm{TW}$ & Diff. $(\%)$ & GB & TW & Diff. (\%) \\
\hline Chemical loss of $\mathrm{O}_{x}(\mathrm{Tg})$ & 1087 & 1099 & $1.1 \%$ & 1252 & 1237 & $-1.2 \%$ & 1116 & 1141 & $2.2 \%$ & 1036 & 1060 & $2.3 \%$ \\
\hline Chemical production of $\mathrm{O}_{x}(\mathrm{Tg})$ & 1197 & 1213 & $1.3 \%$ & 1446 & 1460 & $1.0 \%$ & 1199 & 1211 & $1.0 \%$ & 1042 & 1045 & $0.3 \%$ \\
\hline $\mathrm{O}_{3}$ burden $(\mathrm{Tg})$ & 374 & 340 & $-9.1 \%$ & 394 & 362 & $-8.0 \%$ & 370 & 339 & $-8.4 \%$ & 399 & 352 & $-11.7 \%$ \\
\hline $\begin{array}{l}\text { Lifetime against chemical loss } \\
\left(\mathrm{O}_{3} \text { burden } / \mathrm{O}_{x} \text { loss }\right)\end{array}$ & 31.4 & 28.3 & $-9.8 \%$ & 28.7 & 26.7 & $-6.9 \%$ & 30.3 & 27.1 & $-10.5 \%$ & 35.1 & 30.3 & $-13.6 \%$ \\
\hline
\end{tabular}

Table 3 further presents methane and MCF lifetimes due to reactions with the tropospheric $\mathrm{OH}$. The lifetime calculation follows the formulae used by Yan et al. (2014); it accounts for the grid-box-specific air mass, temperature-dependent reaction constant, $\mathrm{OH}$ content and vertical gradients of methane and MCF with an adjustment coefficient of 0.97 for methane (Predoi-Cross et al., 2006) and 0.92 for MCF (Prather et al., 2012). The coupled system leads to longer lifetimes than the global model alone, by about $5.2 \%$ (from 5.58 to $5.87 \mathrm{yr}$ ) for MCF and $5.1 \%$ (from 9.63 to $10.12 \mathrm{yr}$ ) for methane. These results are closer to the observation-based estimates of MCF lifetime $(6.0 \pm 0.4 \mathrm{yr}$ from Prinn et al., 2005; $6.3 \pm 0.4 \mathrm{yr}$ from Prather et al., 2012) and methane lifetime (10.2 $\pm 0.8 \mathrm{yr}$ from Prinn et al., 2005; $11.2 \pm 1.3 \mathrm{yr}$ from Prather et al., 2012).

\subsection{Delineating the factors driving the difference between the two-way system and the global model alone}

Compared to the global model alone, the two-way coupled system produces lower global tropospheric mean ozone by $9.5 \%$ (Table 3). This difference is driven by four factors including the sub-coarse-grid chemical variability resolved by nested resolution (i.e., emission spatial variability and associated chemical contrast), the sub-coarse-grid variability of non-chemical factors (such as topography), a slight difference in the magnitude of natural emissions (mainly for biogenic NMVOC emissions, Sect. 2) and a slight difference in the magnitude of STE (Sect. 4.1). To delineate the individual effects of these factors, we conducted three additional sensitivity simulations from July 2008 to December 2009 as follows. Results are summarized in Table 5.

The first test simulation was conducted with the global model alone, by adopting at each time step the emissions outputted from the two-way system. Here the global model has the same emission magnitude as the two-way model, which is slightly larger than the original global model simulation (Sect. 2). As a result, the simulated global tropospheric mean ozone was enhanced by $1.1 \%$ relative to the original global model simulation. By linear subtraction, we determine that factors other than emission magnitude lead to an ozone reduction by $10.6 \%$ from the global model alone to the twoway system.
The second test is the counterpart of the first test, by rerunning the two-way system and adopting the emissions outputted from the global model simulation. Here the actual resolution of emissions is $2.5^{\circ}$ long. $\times 2^{\circ}$ lat.; thus, the subcoarse-grid variability of emissions and associated chemical contrast is not resolved. The resulting tropospheric ozone is lower than the original global model by $2.0 \%$. This difference represents the combined effect of the difference in the magnitude of STE and the sub-coarse-grid variability in nonchemical factors.

The third test addresses the slight difference in STE. The test re-run the global model but with a reduction in the STE by $1.0 \%$, by scaling down the Linoz stratospheric ozone production rate. As a result, the global tropospheric mean ozone is reduced by $0.55 \%$. By linear scaling, we determine that a $2.0 \%$ reduction in STE from the global model to the twoway system (Table 3 ) would lead to a $1.1 \%$ reduction in the global tropospheric mean ozone. Combining the result here and from the second test implies that the sub-coarsegrid non-chemical processes would reduce the global tropospheric mean ozone by $0.9 \%$ from the global model alone to the two-way system.

In summary, of the $-9.5 \%$ tropospheric mean ozone change from the global model to the two-way coupled simulation, $-0.9 \%$ is related to sub-coarse-grid non-chemical processes, $-1.1 \%$ is related to the lowered STE, $+1.1 \%$ is associated with the increased natural emission magnitude, and the remaining $-8.6 \%$ represents the effect of subcoarse-grid emission-chemical variability. Thus, the smallscale nonlinear chemical processes (resolved by the nested resolution but not by the coarse resolution) are the dominant driver of the overall ozone difference.

\section{Evaluation of modeled tropospheric ozone against ground, aircraft and satellite measurements}

\subsection{Surface ozone}

As shown in Fig. 1, most ground measurement sites are located in the US (1214 sites from AQS) and Europe (130 sites from EMEP). Averaged over the US AQS sites, the measured annual mean afternoon (12:00-18:00 LT) mean ozone is $35.8 \mathrm{ppb}$ in 2009. The afternoon ozone is slightly higher over Europe, about 37.7 ppb averaged over the EMEP sites. 
Table 5. Contributions of chemical and non-chemical factors to the change in 2009 tropospheric ozone from the global model alone to the two-way coupled system.

\begin{tabular}{lr}
\hline Factors & $\%$ contribution \\
\hline All factors & $-9.5 \%$ \\
A. Higher emission magnitude (mainly related to biogenic NMVOC) & $+1.1 \%$ \\
B. Lower STE & $-1.1 \%$ \\
C. Nonlinear processes within the troposphere & $-9.5 \%$ \\
C1. Small-scale chemical contrast associated with sub-coarse-grid & $-8.6 \%$ \\
$\quad$ variability in emissions of $\mathrm{NO}_{x}$, NMVOC, CO, etc. & $-0.9 \%$ \\
\hline C2. Non-chemical small-scale (sub-coarse-grid) processes & \\
\hline
\end{tabular}

A. Obtained by contrasting simulations of the global model with vs. without adopting the nested model emissions at individual time steps; emissions are regridded from the nested to coarse resolution.

B. Obtained by perturbing the STE in the global model.

C. Residual of "All factors" subtracting A and B.

$\mathrm{C} 1$. Residual of $\mathrm{C}$ subtracting $\mathrm{C} 2$, as driven by small-scale horizontal distributions of emissions resolved on the nested grid but not on the coarse global grid.

C2. Obtained by (1) contrasting simulations of the two-way coupled model with vs. without adopting the global model emissions at individual time steps (here emissions are regridded from the coarse to nested resolution, and are thus resolved only at the scale of the coarse grid), and then (2) subtracting B from the result of (1).

The ozone level is highest over Asia, with a value of $43.1 \mathrm{ppb}$ averaged over the seven WDCGG sites. The afternoon ozone from the 17 WDCGG sites worldwide is about $33.8 \mathrm{ppb}$ on average.

Figure 3 shows the horizontal distributions of annual mean afternoon ozone biases simulated by the global model alone (Fig. 3a, c and e) and by the two-way coupled system (Fig. 3b, d and f), relative to the four ground networks. All model results are derived from the global model component, i.e., from the $2.5^{\circ}$ long. $\times 2^{\circ}$ lat. grid cell covering a given site. The global model tends to overestimate the ozone concentrations (biases range from -5 to $25 \mathrm{ppb}$ ), with a mean bias at $+10.8 \mathrm{ppb}$ globally, $+10.5 \mathrm{ppb}$ over the US, and $+12.1 \mathrm{ppb}$ over Europe. The positive biases exceed $15 \mathrm{ppb}$ at several high-elevation sites of the western US (Fig. 3c) and some coastal sites of Europe (Fig. 3e). These results are broadly consistent with previous multi-model evaluation for the Hemispheric Transport of Air Pollution (HTAP) (Reidmiller et al., 2009) and Atmospheric Composition Change European Network of Excellence (ACCENT) (Dentener et al., 2006) projects that showed an ensemble mean positive bias at 10-20 ppb over the summertime eastern US and 15$20 \mathrm{ppb}$ over South Asia, respectively. Similar model biases are also found from our previous evaluation of MOZART and GEOS-Chem over the US (Lin et al., 2008; Lin and McElroy, 2010). Compared to the global model alone, the two-way coupled system generally reduces the ozone bias worldwide (Fig. 3b, d, and f). The positive bias is reduced to $6.7 \mathrm{ppb}$ globally, $6.6 \mathrm{ppb}$ over the US and $7.5 \mathrm{ppb}$ over Europe. The bias reduction is apparent at several WDCGG sites over the North Pacific and North Atlantic (comparing Fig. 3a and b) and over the eastern US (comparing Fig. 3c and d). The two-way simulation biases against the EMEP measurements are larger than those for the EMEP/MSC-W regional CTM at a horizontal resolution of $50 \mathrm{~km} \times 50 \mathrm{~km}$ driven by year-specific emissions (within $10 \%$ ) (http://emep. int/publ/reports/2014/sup_Status_Report_1_2014.pdf). Our higher biases are partly because the 2005 EMEP $\mathrm{NO}_{x}$ emissions used here are higher than those in 2009 by $25.3 \%$ (http: //webdab.umweltbundesamt.at/official_country_trend.html).

Figure 4 compares the modeled and measured day-to-day time series of regional mean afternoon ozone in 2009 for six regions in the US (from AQS) and two regions in Europe (from EMEP). The regions are defined in Fig. 3c-f, as separated by blue lines. In general, the measured ozone levels are the highest in spring and summer (Fig. 4, black lines), due to stronger STE and/or higher chemical production. Both the global model and the two-way coupled system capture the seasonal variation of measured ozone (Fig. 4, blue and red lines). The global model alone tends to overestimate the observations; the annual mean bias is $9-15 \mathrm{ppb}$ for any given region. Seasonally, the overestimate is the largest in winter over the western US (Fig. 4a and b), in summer over the eastern US and northern Europe (Fig. 4c-g) and in fall over southern Europe (Fig. 4h). The two-way coupled simulation reduces the ozone biases in most days and regions (Fig. 4, red lines). On a seasonal mean basis, the largest reductions occur in winter (2-8 ppb for individual regions), due mainly to much enhanced titration by $\mathrm{NO}_{x}$ (not shown). The bias reductions are smallest in summer $(<3 \mathrm{ppb})$. It is partly because the enhanced ozone production from the increased natural precursor emissions (Table 2) compensate to some extent for a stronger chemical ozone loss; a sensitivity global model simulation adopting emissions in the two-way system produces more summertime ozone than the original global model by $1.7 \mathrm{ppb}$ over the eastern US $\left(100-70^{\circ} \mathrm{W}, 30-50^{\circ} \mathrm{N}\right)$ and by $2.1 \mathrm{ppb}$ over Europe $\left(10^{\circ} \mathrm{W}-30^{\circ} \mathrm{E}, 35-70^{\circ} \mathrm{N}\right)$. Furthermore, although the nested models reduce the net chemical production of ground-level ozone (Sect. 4.3), the effect is partly offset by stronger vertical transport that brings more high-ozone 

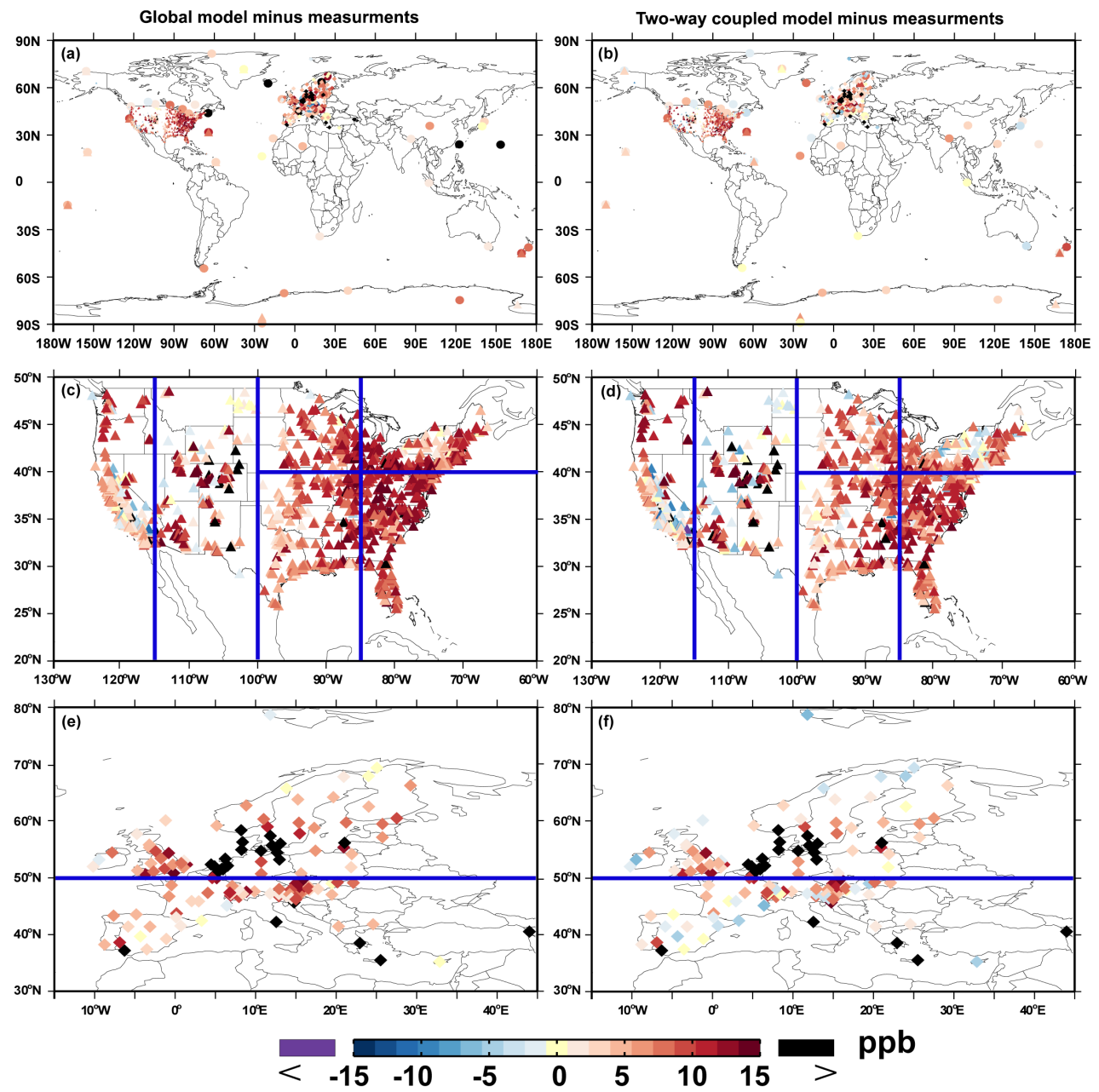

Figure 3. Anneal mean model biases in afternoon (12:00-18:00 LT) mean ground-level ozone for the global model alone (a) and the twoway coupled model (b), with respect to measurements from WDCGG, GMD, AQS and EMEP. The symbol shapes differentiate measurement networks, consistent with Fig. 1 (circle for WDCGG, large triangle for GMD, small triangle for AQS, and diamond for EMEP). The US and European domains are enlarged in panels (c-f) to better show spatial distributions. Blue lines separate the regions presented in Fig. 4.

air aloft down to the ground (Roelofs et al., 2003; M. Lin et al., 2012b). The persistent large summertime bias may also be due to some non-resolution-dependent factors such as isoprene nitrate chemistry and dry deposition (Lin et al., 2008; Fiore et al., 2014; Monks et al., 2015). Although the two-way coupling leads to a relatively small improvement in summertime ground-level ozone simulations over the US and Europe (Fig. 4), the coupling results in large error reductions for tropospheric ozone (see Sect. 5.2 and 5.3 below).

Figure 5 compares the day-to-day time series of modeled afternoon ozone against the observations at 12 background sites from WDCGG (panels a, b for Europe, c, d for US, e-g for Asia, h for North Pole, i for Mauna Loa in the North Pacific and $\mathrm{j}$ for the Southern Hemisphere). Each observation site provides a nearly complete hourly data set for model evaluation. Although the global model alone and the two-way coupled system generally overestimate the ob- served ozone, both simulations reproduce the observed temporal patterns fairly well. At 11 sites, the correlation between modeled and observed ozone time series exceeds 0.61 and 0.55 for the coupled system and the global model, respectively. At six sites, the correlation exceeds 0.75 and 0.71 , respectively. Compared to the global model alone, the coupled simulation is closer to the observations with a lower bias and higher correlation. At MLO (outside the nested domains, Fig. 5i), the coupled system produces a positive bias of $3.0 \mathrm{ppb}$ with a correlation coefficient at 0.61 , compared to the values at $8.2 \mathrm{ppb}$ and 0.59 for the global model alone. Over the three Asian sites (Figs. $5 \mathrm{e}-\mathrm{g}$ ), the coupled system reduces the biases by 7.1, 5.1 and $6.1 \mathrm{ppb}$. Although both simulations capture the observed temporal variability at the two tropical Asian sites (Fig. 5e and f) with correlation coefficients exceeding 0.66 , their performances are poorer at the mid-latitude mountain site (Fig. $5 \mathrm{~g}$ ) due to large overes- 

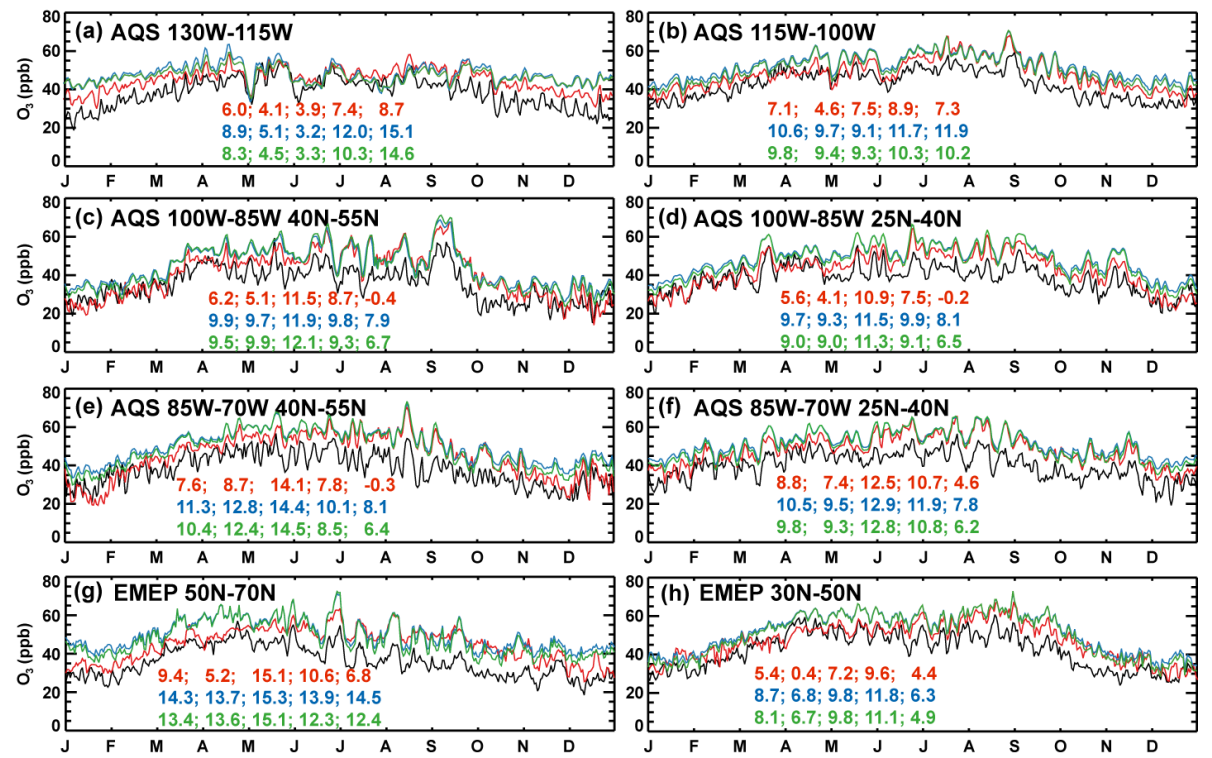

Figure 4. Day-to-day time series of afternoon (12:00-18:00 LT) mean ground-level ozone from AQS and EMEP measurements (black lines) and from model simulations (red lines for two-way coupled system, blue lines for global model alone and green lines for one-way nested models). Data are averaged over individual triangular regions indicated in Fig. 3. Numbers shown in each panel are mean model biases for annul mean, spring (MAM), summer (JJA), fall (SON) and winter (DJF).
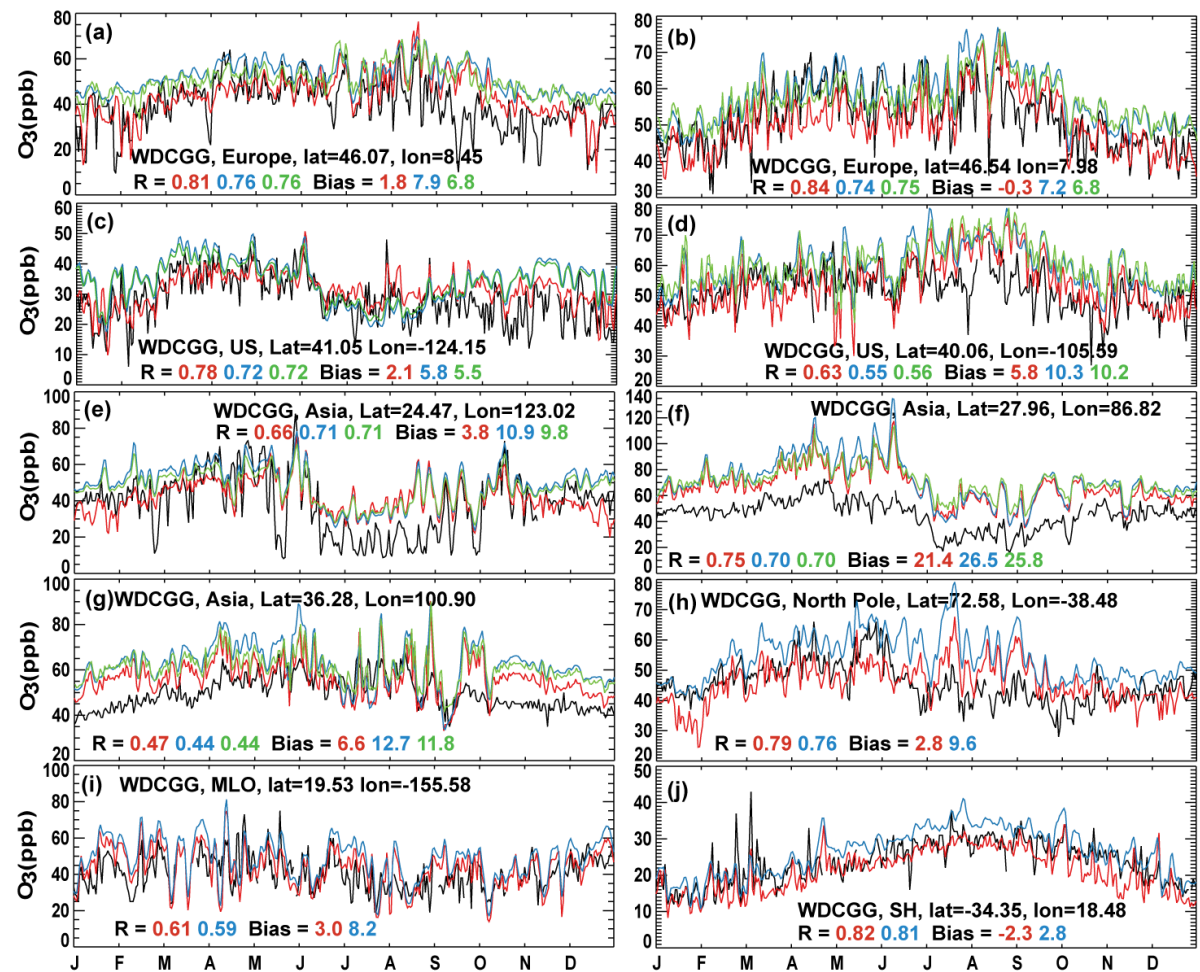

Figure 5. Day-to-day time series of afternoon (12:00-18:00 LT) mean surface ozone observed at 12 background sites from WDCGG (black lines) and coincident model simulations (red lines for two-way simulations, blue lines for global model alone and green lines for one-way nested simulations). Also shown in each panel are latitude, longitude and model correlation with and bias against the observations. 
timates in the cold seasons and much smaller biases in the warm seasons. Nevertheless, the spring-summer high values at these Asian sites are captured fairly well by both simulations. The spring-summer peaks are also found for other Asian regions (Lin et al., 2009; Wang et al., 2011).

Figure 6 further presents for individual sites the day-today correlation and mean bias of simulated afternoon ozone relative to the observations. Figure 6 a presents the results for all 1420 sites. It shows that compared to the global model alone, the two-way coupled simulation increases the correlation for 1179 sites and decreases the bias for 1221 sites. Averaged over all sites, the correlation is increased from 0.53 to 0.68 , and the bias is reduced from 10.8 to $6.7 \mathrm{ppb}$. Figure $6 \mathrm{~b}$ further shows the evaluation results at the 25 sites outside the nested domains from WDCGG and GMD. The two-way coupled simulation results are within $5 \mathrm{ppb}$ of the observations at 21 sites, compared to 17 sites for the global model alone. Averaged across all the 25 sites, the coupled simulation has a mean bias at $2.2 \mathrm{ppb}$ and correlation at 0.74 , compared to the global model bias at $4.6 \mathrm{ppb}$ and correlation at 0.61 . These results again indicate the improvement by the two-way coupling for ozone simulations both within and outside the nested domains.

\section{Improvement of two-way coupling upon one-way nesting}

Within the nested domains, the two-way coupled simulation improves upon the traditional one-way nested simulations, because of the improved ozone simulation at the global scale that in turn affects the LBCs of the nested models. To illustrate this feedback effect, we conducted additional nested model simulations between July 2008 and December 2009 in a one-way nesting mode. Here the nested models take the LBCs from the global model without affecting the global model simulation, with other model setups the same as the nested models in the two-way coupled system. Results are regridded to $2.5^{\circ}$ long. $\times 2^{\circ}$ lat. for consistency with the twoway and the global model results; we note that for the comparison in this section, the effect of this regridding is negligible.

The green lines in Fig. 4 show the regional average oneway nested simulation results over eight regions of the US and Europe. Compared to the global model alone (blue lines), the one-way models produce lower biases on an annual mean basis and for almost all seasons, reflecting the effect of finer resolution prior to accounting for the improved LBCs, broadly consistent with previous regional model studies (Fiore et al., 2003; Huang et al., 2008; Emery et al., 2012). The improvements are most obvious in fall and winter, by up to 1-2 ppb on a seasonal mean basis. The smallest differences in summer are a result of better resolved chemical regimes compensated by higher natural emissions and stronger vertical transport (see above discussion for two-way vs. global). The two-way coupled system (red lines) produces much smaller biases than the one-way nested simulations due
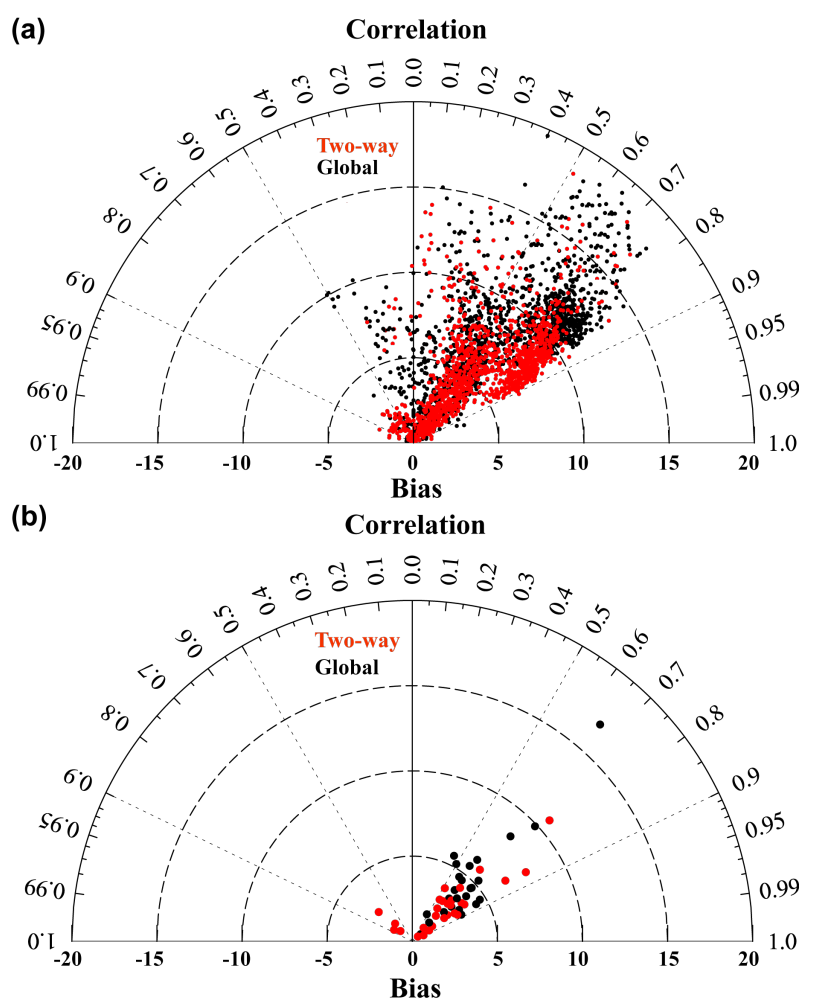

Figure 6. (a) Mean bias and day-to-day correlation of afternoon (12:00-18:00 LT) mean ground-level ozone for model simulations with respect to measurements from WDCGG, GMD, EMEP and AQS (a total of 1420 sites). (b) Similar to panel (a) but with respect to measurements outside the three nested domains from WDCGG and GMD (a total of 25 sites).

to improved LBCs. For any of these eight regions, on a regional annual mean basis, the amount of bias reduction (1.0$4.0 \mathrm{ppb}$ ) from the one-way nesting to the two-way coupling is larger than the reduction $(0.4-0.9 \mathrm{ppb})$ from the global modeling to the one-way nesting by a factor of 1-7. The large influence of LBCs on the one-way nested modeling was also found by previous studies (e.g., Huang et al., 2008). Our results suggest that the improved LBCs through two-way coupling are very beneficial for the nested models.

Figure $5 \mathrm{a}-\mathrm{g}$ contrast the one-way simulated ozone time series (green lines) at the seven background sites within the nested domains against the simulations of the two-way system (red lines) and the global model alone (blue lines). At any site, the one-way nested model produces lower ozone than the global model alone on average, with a difference of up to $10 \mathrm{ppb}$ in some days. This leads to a lower bias against the observations, consistent with previous regional model studies (Fiore et al., 2003; Huang et al., 2008; Emery et al., 2012). Furthermore, the two-way coupled simulation produces lower ozone than the one-way nested model, leading to a lower bias and higher correlation against the obser- 

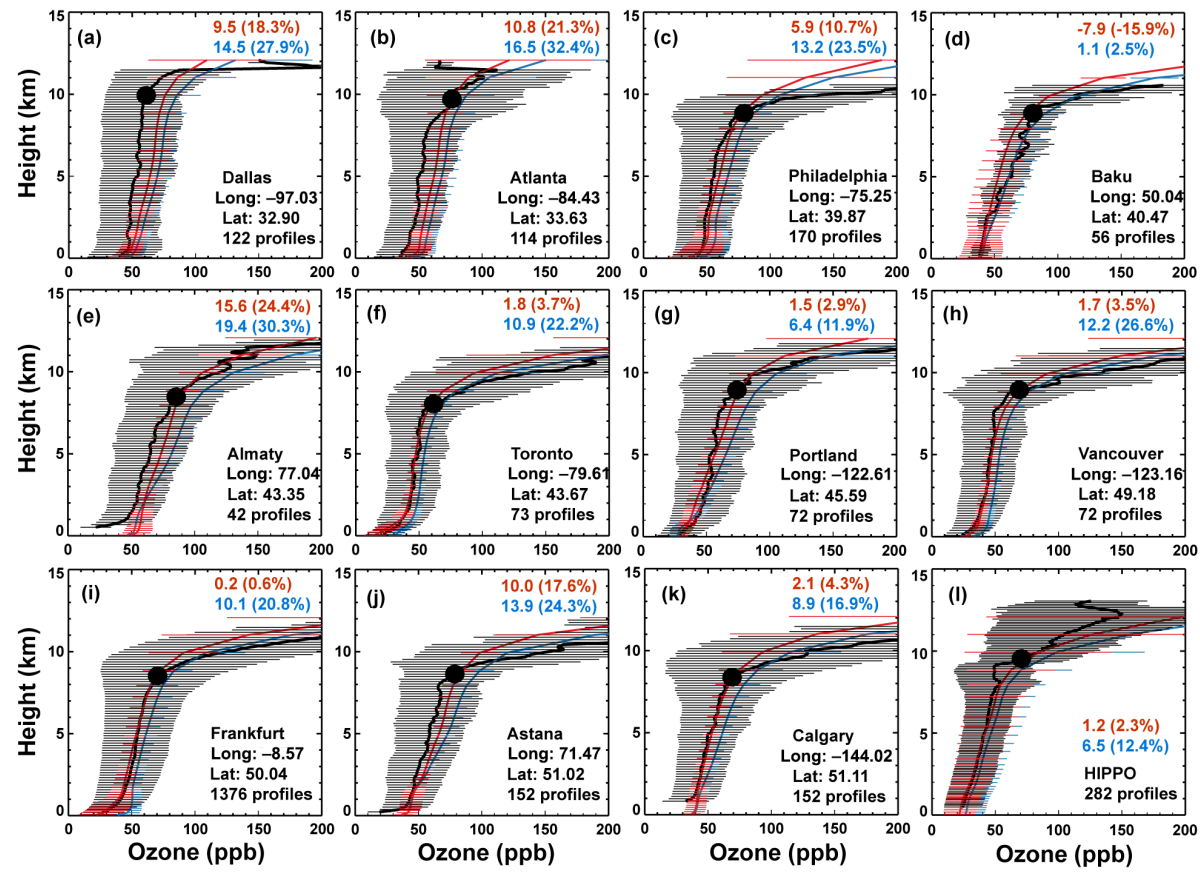

Figure 7. Measured (black) and simulated (red for two-way coupled model and blue for global model alone) vertical profiles of ozone in 2009 for the MOZAIC (a-k) and HIPPO campaigns (l). MOZAIC measurements are from the ground level $(0.075 \mathrm{~km})$ to the UTLS at $0.15 \mathrm{~km}$ intervals, as averaged over all profiles. HIPPO data are averaged over all profiles at $0.1 \mathrm{~km}$ intervals. Model results are sampled at times and locations coincident to the measurements, except that the model vertical layers are kept for clarity. Horizontal lines indicate 1 standard deviation. Also shown in each panel are the city name, longitude, latitude, number of profiles and mean model biases below $9 \mathrm{~km}$ (the mean tropopause height). The black dot in each panel depicts the average tropopause height calculated from the two-way coupled model.

vations. This again indicates an important additional effect by accounting for improved LBCs via the two-way coupling.

\subsection{Tropospheric ozone profile}

The black lines in Fig. 7a-k show the measured vertical profiles of tropospheric ozone averaged over 2009 at individual MOZAIC sites. In general, the measured ozone increases with height, from $20-40 \mathrm{ppb}$ in the lower troposphere to 40 $70 \mathrm{ppb}$ at $5 \mathrm{~km}$, and to larger values in the upper troposphere. For the HIPPO campaigns (black line in Fig. 71), the average ozone mixing ratio is between 20 and $50 \mathrm{ppb}$ below $9 \mathrm{~km}$.

The red and blue lines in Fig. 7 show the ozone profiles simulated by the two-way coupled system and the global model alone, respectively. Here the model evaluation is focused on ozone biases below $9 \mathrm{~km}$, the mean tropopause height. Both simulations capture the general vertical structures of MOZAIC and HIPPO ozone. Below $9 \mathrm{~km}$, the global model generally overestimates the measured ozone, with a positive bias by $10.4 \mathrm{ppb}$ averaged vertically and across all profiles. This overestimate is consistent with the positive bias, especially north of $30^{\circ} \mathrm{N}$, reported from the ACCENT and ACCMIP model ensemble evaluation against ozonesonde data (Stevenson at al., 2006; Young et al., 2013). The coupled system produces lower ozone concentrations in the troposphere $(0-9 \mathrm{~km})$ than the global model alone.
This translates to ozone bias reductions by $3-11 \mathrm{ppb}$ at most MOZAIC sites (in the polluted areas) and by $5.3 \mathrm{ppb}$ for HIPPO profiles (in the remote areas), averaged over $0-9 \mathrm{~km}$. These improvements are a result of interactions between improved ozone simulations over pollution source regions and improved simulations of background ozone, as initially driven by a higher resolution over the source regions.

Figure 7 shows that for the MOZAIC sites, the observed ozone variability at a particular height of the profile is much larger than the modeled variability. This is because the observation is sampled at every $0.15 \mathrm{~km}$ vertically, at a much finer resolution than the vertical resolution of the model. When the observations are mapped to the vertical resolution of the model, the observed variability is greatly reduced to a level comparable to the modeled variability (not shown).

Figure 8 further shows the ozone profiles in individual seasons of 2009 at Frankfurt. With several hundred profiles in each season, this site allows for a detailed seasonal analysis. Again, although both the two-way coupled system and the global model alone capture the general vertical distribution of ozone in any given season, the coupled system leads to much lower biases below $9 \mathrm{~km}$. 

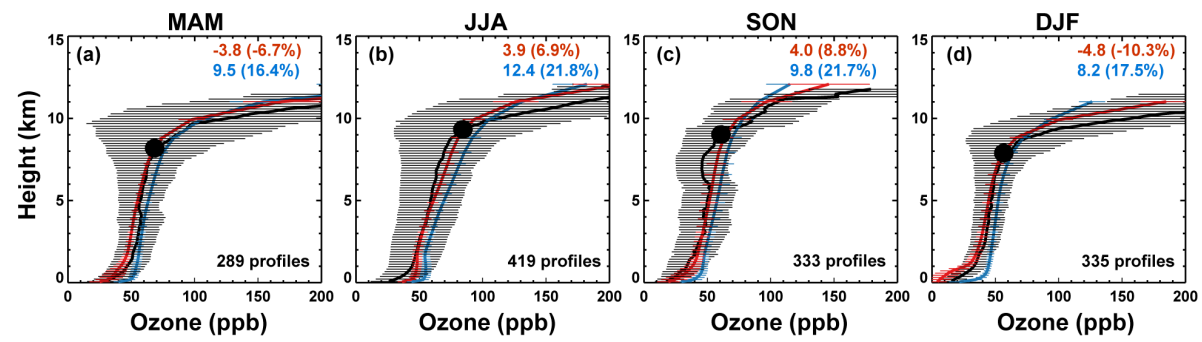

Figure 8. Similar to Fig. 7 but for seasonal profiles at Frankfurt from the MOZAIC program.

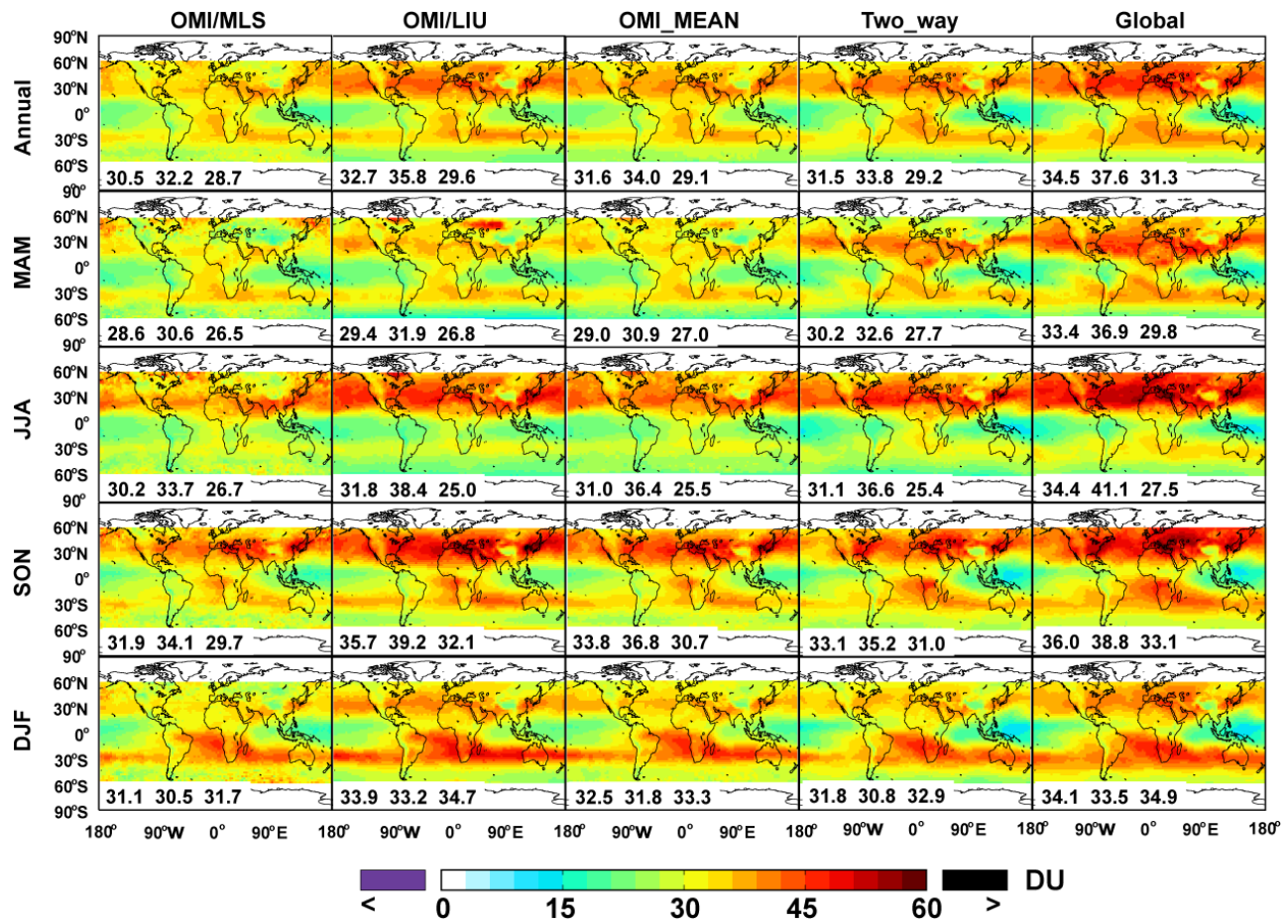

Figure 9. Measured and modeled annual and seasonal mean tropospheric ozone columns from $60^{\circ} \mathrm{S}$ to $60^{\circ} \mathrm{N}$ in 2009 : (from left to right) OMI/MLS, OMI retrieval by Liu et al. (2010), average of the two satellite data sets, simulation of the two-way coupled system, and simulation of the global model alone. Also shown in each panel are global, NH and $\mathrm{SH}$ means.

\subsection{Tropospheric column ozone}

Figure 9 presents the horizontal distributions of TCO in individual seasons from OMI/MLS, OMI/LIU, their average OMI_MEAN, the two-way coupled system, and the global model alone. OMI/MLS and OMI/LIU produce similar seasonal and spatial distributions of TCO, with lower values in the tropics but higher values in the northern mid-latitudes (especially in the Northern Hemisphere (NH) summer and fall) and near $30^{\circ} \mathrm{S}$. In general, OMI/LIU produces higher TCO values than OMI/MLS by $0.8 \mathrm{DU}(2.8 \%), 1.6 \mathrm{DU}$ $(5.3 \%), 3.8 \mathrm{DU}(11.9 \%)$ and $2.8 \mathrm{DU}(9.0 \%)$ in $\mathrm{NH}$ spring, summer, fall and winter, respectively. These differences are broadly consistent with the uncertainties in OMI/MLS and $\mathrm{OMI} / \mathrm{LIU}$ discussed in Sect. 3.3. We thus use their average, OMI_MEAN, for model evaluation.
Figure 9 shows that both the global model alone and the coupled system reproduce the general seasonal and spatial structures of OMI_MEAN TCO. The global model tends to overestimate the seasonal TCO in OMI_MEAN, with a global mean bias of 4.4 DU (15.2\%), 3.4 DU (10.9\%), $2.2 \mathrm{DU}(6.5 \%)$, and 1.6 DU (4.9\%) in NH spring, summer, fall, and winter, respectively. The positive bias is more significant in the NH (annual mean bias $=3.6 \mathrm{DU}$ ) than in the Southern Hemisphere $(\mathrm{SH}$, bias $=2.2 \mathrm{DU})$. The large $\mathrm{NH}$ overestimate was found also for the ACCMIP model ensemble (Young et al., 2013). Compared to the global model alone, the coupled system reduces the annual average TCO by $3.0 \mathrm{DU}(9.5 \%)$ globally, by $3.8 \mathrm{DU}$ in the $\mathrm{NH}$, and by $2.1 \mathrm{DU}$ in the SH. The coupled system also leads to TCO values closer to OMI_MEAN, with a global mean bias of $1.2 \mathrm{DU}(4.1 \%)$ in $\mathrm{NH}$ spring, $0.1 \mathrm{DU}(0.3 \%)$ in summer, 
$-0.7 \mathrm{DU}(-2.1 \%)$ in fall and $-0.7 \mathrm{DU}(-2.2 \%)$ in winter. The model improvements are more significant in the $\mathrm{NH}$.

\section{Conclusions}

This study evaluates the effects on the global tropospheric ozone of nonlinear small-scale chemical and physical processes over the three major pollution source regions (Asia, North America, and Europe) not resolved by a typical global model (at a $\sim 200 \mathrm{~km}$ resolution). For this purpose, we simulate the tropospheric ozone in 2009 simulated by a two-way coupled system integrating the global GEOS-Chem CTM (at $2.5^{\circ}$ long. $\times 2^{\circ}$ lat.) and its three fine-resolution nested models (at $0.667^{\circ}$ long. $\times 0.5^{\circ}$ lat.) covering Asia, North America and Europe. The nested models better capture nonlinear small-scale processes within the nested domains; and the two-way coupling allows such improvements to have a global impact, which in turn improves the LBCs of the nested models.

The coupled system is compared against the coarse global model alone, by employing a suite of ozone measurements in 2009 from four ground networks (WDCGG, GMD, AQS in the US, and EMEP in Europe, with 1420 sites), MOZAIC and HIPPO aircraft campaigns, and two OMI TCO products. Model evaluation clearly indicates the superiority of the twoway coupled system. Compared to the global model alone, the coupled system produces afternoon (12:00-18:00 LT) mean ground-level ozone much closer to the measurements. On an annual mean basis, the model bias is reduced by $4.1 \mathrm{ppb}$ (from 10.8 to $6.7 \mathrm{ppb}$ ) globally, by $3.9 \mathrm{ppb}$ (from 10.5 to $6.6 \mathrm{ppb}$ ) over the US, and by $4.6 \mathrm{ppb}$ (from 12.1 to $7.5 \mathrm{ppb}$ ) over Europe. The coupled system also enhances the correlation to the measurements in day-to-day ozone variability from 0.53 to 0.68 , averaged over the 1420 sites. Although both the global model alone and the coupled system capture the vertical distributions of ozone measured from MOZAIC and HIPPO, the coupled system produces lower ozone values. This leads to bias reductions by $3-10 \mathrm{ppb}$ at most MOZAIC sites and by $5.3 \mathrm{ppb}$ for HIPPO profiles (for ozone averaged over $0-9 \mathrm{~km}$ ). The coupled system also produces lower TCO values than the global model alone, with a global annual mean reduction by $3.0 \mathrm{DU}(9.5 \%)$, leading to better agreement with OMI data in all seasons. These model improvements are mainly driven by better representation of spatially inhomogeneous nonlinear ozone chemistry associated with sub-coarse-grid spatial variability of precursor emissions.

Within the nested domains, the two-way coupling also leads to smaller surface ozone biases than a traditional oneway nested model setup. This is because the two-way coupling improves the ozone simulation in the global domain, which in turn improves the LBCs of the nested models. On a regional annual mean basis, the bias reduction from the one-way nesting to the two-way coupling is larger than the reduction from the global modeling to the one-way nesting by a factor of 1-7 over the US and Europe. This result has important implications for nested/regional model studies of surface air quality.

Compared to the global model alone, the two-way coupled system also reduces the global tropospheric mean $\mathrm{OH}$ by $5.0 \%$, with corresponding enhancements in methane lifetime (by $5.1 \%$ ), MCF lifetime (by $5.2 \%$ ) and CO burden (by $10.8 \%$ ). The improved quantities are closer to observationbased estimates (Prinn et al., 2005; Prather et al., 2012; Yan et al., 2014). These results are consistent with our previous analysis (Yan et al., 2014), and they point to the importance of small-scale processes to the global chemistry. Similar simulations with other global models would further test the importance of small-scale chemical variability for the global ozone chemistry.

At last, we note that the coupled system requires an amount of computational resource affordable for most users, i.e., 32 cores compared to eight cores for the global model alone for a similar wall-clock time. As a global highresolution simulation is often prohibited by large computational costs, we suggest a low-cost two-way coupled system integrating global and nested CTMs, like ours, to be a viable choice for most researchers.

Acknowledgements. This research is supported by the National Natural Science Foundation of China, grants 41422502 and 41175127 , and the 973 program, grant 2014CB441303. We acknowledge the free use of ozone data from WDCGG (http://ds.data. jma.go.jp/gmd/wdcgg/), GMD (http://www.esrl.noaa.gov/gmd/), EMEP (http://www.nilu.no/projects/ccc/emepdata.html), AQS (http://aqsdr1.epa.gov/aqsweb/aqstmp/airdata/download_files.html), MOZAIC-IAGOS (http://www.iagos.fr/web/), HIPPO (http://hippo.ornl.gov/dataaccess), OMI/MLS (http://ozoneaq. gsfc.nasa.gov/) and OMI TCO data from Xiong Liu. We thank the European Commission for the support to the MOZAIC project (1994-2003) and the preparatory phase of IAGOS (2005-2012) partner institutions of the IAGOS Research Infrastructure (FZJ, DLR, MPI, KIT in Germany, CNRS, CNES, Météo-France in France and University of Manchester in United Kingdom), ETHER (CNES-CNRS/INSU) for hosting the database, the participating airlines (Lufthansa, Air France, Austrian, China Airlines, Iberia, Cathay Pacific) for the transport free of charge of the instrumentation.

Edited by: Y. Cheng 


\section{References}

Auvray, M. and Bey, I.: Long-range transport to Europe: seasonal variations and implications for the European ozone budget, J. Geophys. Res.-Atmos., 110, D11303, doi:10.1029/2004jd005503, 2005.

Bertram, T. H., Thornton, J. A., Riedel, T. P., Middlebrook, A. M., Bahreini, R., Bates, T. S., Quinn, P. K., and Coffman, D. J.: Direct observations of $\mathrm{N}_{2} \mathrm{O}_{5}$ reactivity on ambient aerosol particles, Geophys. Res. Lett., 36, L19803, doi:10.1029/2009g1040248, 2009

Bond, T. C., Bhardwaj, E., Dong, R., Jogani, R., Jung, S., Roden, C., Streets, D. G., and Trautmann, N. M.: Historical emissions of black and organic carbon aerosol from energy-related combustion, 1850-2000, Global Biogeochem. Cy., 21, GB2018, doi:10.1029/2006GB002840, 2007.

Bouwman, A. F., Lee, D. S., Asman, W. A. H., Dentener, F. J., Van Der Hoek, K. W., and Olivier, J. G. J.: A global high-resolution emission inventory for ammonia, Global Biogeochem. Cy., 11, 561-587, 1997.

Chen, D., Wang, Y., McElroy, M. B., He, K., Yantosca, R. M., and Le Sager, P.: Regional CO pollution and export in China simulated by the high-resolution nested-grid GEOS-Chem model, Atmos. Chem. Phys., 9, 3825-3839, doi:10.5194/acp-9-3825-2009, 2009.

Dentener, F., Stevenson, D., Ellingsen, K., van Noije, T., Schultz, M., Amann, M., Atherton, C., Bell, N., Bergmann, D., Bey, I., Bouwman, L., Butler, T., Cofala, J., Collins, B., Drevet, J., Doherty, R., Eickhout, B., Eskes, H., Fiore, A., Gauss, M., Hauglustaine, D., Horowitz, L., Isaksen, I. S. A., Josse, B., Lawrence, M., Krol, M., Lamarque, J. F., Montanaro, V., Muller, J. F., Peuch, V. H., Pitari, G., Pyle, J., Rast, S., Rodriguez, J., Sanderson, M., Savage, N. H., Shindell, D., Strahan, S., Szopa, S., Sudo, K., Van Dingenen, R., Wild, O., and Zeng, G.: The global atmospheric environment for the next generation, Environ. Sci. Technol., 40, 3586-3594, doi:10.1021/es0523845, 2006.

Doherty, R. M., Wild, O., Shindell, D. T., Zeng, G., MacKenzie, I. A., Collins, W. J., Fiore, A. M., Stevenson, D. S., Dentener, F. J., Schultz, M. G., Hess, P., Derwent, R. G., and Keating, T. J.: Impacts of climate change on surface ozone and intercontinental ozone pollution: A multi-model study, J. Geophys. Res.-Atmos., 118, 3744-3763, doi:10.1002/jgrd.50266, 2013.

Eastham, S. D., Weisenstein, D. K., and Barrett, S. R. H.: Development and evaluation of the unified troposphericstratospheric chemistry extension (UCX) for the global chemistry-transport model GEOS-Chem, Atmos. Environ., 89, 52-63, doi:10.1016/j.atmosenv.2014.02.001, 2014.

Emery, C., Jung, J., Downey, N., Johnson, J., Jimenez, M., Yarvvood, G., and Morris, R.: Regional and global modeling estimates of policy relevant background ozone over the United States, Atmos. Environ., 47, 206-217, doi:10.1016/j.atmosenv.2011.11.012, 2012.

Emmons, L. K., Apel, E. C., Lamarque, J.-F., Hess, P. G., Avery, M., Blake, D., Brune, W., Campos, T., Crawford, J., DeCarlo, P. F., Hall, S., Heikes, B., Holloway, J., Jimenez, J. L., Knapp, D. J., Kok, G., Mena-Carrasco, M., Olson, J., O’Sullivan, D., Sachse, G., Walega, J., Weibring, P., Weinheimer, A., and Wiedinmyer, C.: Impact of Mexico City emissions on regional air quality from MOZART-4 simulations, Atmos. Chem. Phys., 10, 6195-6212, doi:10.5194/acp-10-6195-2010, 2010.
Evans, M. J. and Jacob, D. J.: Impact of new laboratory studies of N2O5 hydrolysis on global model budgets of tropospheric nitrogen oxides, ozone, and OH, Geophys. Res. Lett., 32, L09813, doi:10.1029/2005g1022469, 2005.

Fiore, A. M., Jacob, D. J., Mathur, R., and Martin, R. V.: Application of empirical orthogonal functions to evaluate ozone simulations with regional and global models, J. Geophys. Res.-Atmos., 108, 4431, doi:10.1029/2002jd003151, 2003.

Fiore, A. M., Dentener, F. J., Wild, O., Cuvelier, C., Schultz, M. G., Hess, P., Textor, C., Schulz, M., Doherty, R. M., Horowitz, L. W., MacKenzie, I. A., Sanderson, M. G., Shindell, D. T., Stevenson, D. S., Szopa, S., Van Dingenen, R., Zeng, G., Atherton, C., Bergmann, D., Bey, I., Carmichael, G., Collins, W. J., Duncan, B. N., Faluvegi, G., Folberth, G., Gauss, M., Gong, S., Hauglustaine, D., Holloway, T., Isaksen, I. S. A., Jacob, D. J., Jonson, J. E., Kaminski, J. W., Keating, T. J., Lupu, A., Marmer, E., Montanaro, V., Park, R. J., Pitari, G., Pringle, K. J., Pyle, J. A., Schroeder, S., Vivanco, M. G., Wind, P., Wojcik, G., Wu, S., and Zuber, A.: Multimodel estimates of intercontinental sourcereceptor relationships for ozone pollution, J. Geophys. Res., 114, D04301, doi:10.1029/2008jd010816, 2009.

Fiore, A. M., Oberman, J. T., Lin, M. Y., Zhang, L., Clifton, O. E., Jacob, D. J., Naik, V., Horowitz, L. W., and Pinto, J. P.: Estimating North American background ozone in US surface air with two independent global models: Variability, uncertainties, and recommendations, Atmos. Environ., 96, 284-300, doi:10.1016/j.atmosenv.2014.07.045, 2014.

Fu, T.-M., Zheng, Y., Paulot, F., Mao, J., and Yantosca, R. M.: Positive but variable sensitivity of August surface ozone to largescale warming in the southeast United States, Nature Climate Change, 5, 454-458, doi:10.1038/nclimate2567, 2015.

Guenther, A. B., Jiang, X., Heald, C. L., Sakulyanontvittaya, T., Duhl, T., Emmons, L. K., and Wang, X.: The Model of Emissions of Gases and Aerosols from Nature version 2.1 (MEGAN2.1): an extended and updated framework for modeling biogenic emissions, Geosci. Model Dev., 5, 1471-1492, doi:10.5194/gmd-51471-2012, 2012.

Holtslag, A. A. M. and Boville, B. A.: Local Versus Nonlocal Boundary-Layer Diffusion in a Global Climate Model, J. Climate, 6, 1825-1842, doi:10.1175/15200442(1993)006<1825:LVNBLD>2.0.CO;2, 1993.

HTAP: Hemispheric Transport of Air Pollution 2010 Executive Summary ECE/EB.AIR/2010/10 Corrected, United Nations, available at: http://www.htap.org/publications/2010_report/ 2010_Final_Report/EBMeeting2010.pdf (last access: 1 February 2015), 2010.

Hu, L., Millet, D. B., Baasandorj, M., Griffis, T. J., Travis, K. R., Tessum, C. W., Marshall, J. D., Reinhart, W. F., Mikoviny, T., Mueller, M., Wisthaler, A., Graus, M., Warneke, C., and de Gouw, J.: Emissions of $\mathrm{C}_{6} \mathrm{C}_{8}$ aromatic compounds in the United States: Constraints from tall tower and aircraft measurements, J. Geophys. Res.-Atmos., 120, 826-842, doi:10.1002/2014jd022627, 2015.

Huang, H. C., Lin, J.-T., Tao, Z. N., Choi, H., Patten, K., Kunkel, K., Xu, M., Zhu, J. H., Liang, X. Z., Williams, A., Caughey, M., Wuebbles, D. J., and Wang, J. L.: Impacts of long-range transport of global pollutants and precursor gases on US air quality under future climatic conditions, J. Geophys. Res.-Atmos., 113, D19307, doi:10.1029/2007jd009469, 2008. 
Huang, M., Carmichael, G. R., Adhikary, B., Spak, S. N., Kulkarni, S., Cheng, Y. F., Wei, C., Tang, Y., Parrish, D. D., Oltmans, S. J., D’Allura, A., Kaduwela, A., Cai, C., Weinheimer, A. J., Wong, M., Pierce, R. B., Al-Saadi, J. A., Streets, D. G., and Zhang, Q.: Impacts of transported background ozone on California air quality during the ARCTAS-CARB period - a multi-scale modeling study, Atmos. Chem. Phys., 10, 6947-6968, doi:10.5194/acp-106947-2010, 2010.

Huang, X., Song, Y., Li, M., Li, J., Huo, Q., Cai, X., Zhu, T., Hu, M., and Zhang, H.: A high-resolution ammonia emission inventory in China, Global Biogeochem. Cy., 26, GB1030, doi:10.1029/2011gb004161, 2012.

Hudman, R. C., Moore, N. E., Mebust, A. K., Martin, R. V., Russell, A. R., Valin, L. C., and Cohen, R. C.: Steps towards a mechanistic model of global soil nitric oxide emissions: implementation and space based-constraints, Atmos. Chem. Phys., 12, 7779-7795, doi:10.5194/acp-12-7779-2012, 2012.

Janssens-Maenhout, G., Petrescu, A. M. R., Muntean, M., and Blujdea, V.: Verifying Greenhouse Gas Emissions: Methods to Support International Climate Agreements, The National Academies Press, 124 pp., 132-133, doi:10.1080/20430779.2011.579358, 2010.

Kim, P. S., Jacob, D. J., Liu, X., Warner, J. X., Yang, K., Chance, K., Thouret, V., and Nedelec, P.: Global ozone-CO correlations from OMI and AIRS: constraints on tropospheric ozone sources, Atmos. Chem. Phys., 13, 9321-9335, doi:10.5194/acp-13-93212013, 2013.

Kort, E. A., Wofsy, S. C., Daube, B. C., Diao, M., Elkins, J. W., Gao, R. S., Hintsa, E. J., Hurst, D. F., Jimenez, R., Moore, F. L., Spackman, J. R., and Zondlo, M. A.: Atmospheric observations of Arctic Ocean methane emissions up to 82 degrees north, Nat. Geosci., 5, 318-321, doi:10.1038/ngeo1452, 2012.

Kuhlmann, G., Lam, Y. F., Cheung, H. M., Hartl, A., Fung, J. C. H., Chan, P. W., and Wenig, M. O.: Development of a custom $\mathrm{OMI} \mathrm{NO}_{2}$ data product for evaluating biases in a regional chemistry transport model, Atmos. Chem. Phys., 15, 5627-5644, doi:10.5194/acp-15-5627-2015, 2015.

Kuhns, H., Etyemezian, V., Green, M., Hendrickson, K., McGown, M., Barton, K., and Pitchford, M.: Vehicle-based road dust emission measurement - Part II: Effect of precipitation, wintertime road sanding, and street sweepers on inferred PM10 emission potentials from paved and unpaved roads, Atmos. Environ., 37, 4573-4582, doi:10.1016/s1352-2310(03)00529-6, 2003.

Lin, J.-T. and McElroy, M. B.: Impacts of boundary layer mixing on pollutant vertical profiles in the lower troposphere: Implications to satellite remote sensing, Atmos. Environ., 44, 17261739, doi:10.1016/j.atmosenv.2010.02.009, 2010.

Lin, J.-T., Youn, D., Liang, X. Z., and Wuebbles, D. J.: Global model simulation of summertime US ozone diurnal cycle and its sensitivity to PBL mixing, spatial resolution, and emissions, Atmos. Environ., 42, 8470-8483, doi:10.1016/j.atmosenv.2008.08.012, 2008.

Lin, J.-T., Liu, Z., Zhang, Q., Liu, H., Mao, J., and Zhuang, G.: Modeling uncertainties for tropospheric nitrogen dioxide columns affecting satellite-based inverse modeling of nitrogen oxides emissions, Atmos. Chem. Phys., 12, 12255-12275, doi:10.5194/acp-12-12255-2012, 2012.

Lin, J.-T., Pan, D., Davis, S. J., Zhang, Q., He, K., Wang, C., Streets, D. G., Wuebbles, D. J., and Guan, D.: China's international trade and air pollution in the United States, P. Natl. Acad. Sci. USA, 111, 1736-1741, doi:10.1073/pnas.1312860111, 2014.

Lin, M., Holloway, T., Oki, T., Streets, D. G., and Richter, A.: Multiscale model analysis of boundary layer ozone over East Asia, Atmos. Chem. Phys., 9, 3277-3301, doi:10.5194/acp-9-3277-2009, 2009.

Lin, M., Holloway, T., Carmichael, G. R., and Fiore, A. M.: Quantifying pollution inflow and outflow over East Asia in spring with regional and global models, Atmos. Chem. Phys., 10, 42214239, doi:10.5194/acp-10-4221-2010, 2010.

Lin, M., Fiore, A. M., Horowitz, L. W., Cooper, O. R., Naik, V., Holloway, J., Johnson, B. J., Middlebrook, A. M., Oltmans, S. J., Pollack, I. B., Ryerson, T. B., Warner, J. X., Wiedinmyer, C., Wilson, J., and Wyman, B.: Transport of Asian ozone pollution into surface air over the western United States in spring, J. Geophys. Res., 117, D00V07, doi:10.1029/2011JD016961, 2012a.

Lin, M., Fiore, A. M., Cooper, O. R., Horowitz, L. W., Langford, A. O., Levy II., H., Johnson, B. J., Naik, V., Oltmans, S. J., and Senff, C.: Springtime high surface ozone events over the western United States: Quantifying the role of stratospheric intrusions, J. Geophys. Res., 117, D00V22, doi:10.1029/2012JD018151, 2012b.

Lin, M., Fiore, A. M., Horowitz, L. W., Langford, A. O., Oltmans, S. J., Tarasick, D., and Rieder, H. E.: Climate variability modulates western US ozone air quality in spring via deep stratospheric intrusions, Nat. Comm., 6, 7105, doi:10.1038/ncomms8105, 2015.

Liu, X., Chance, K., and Kurosu, T. P.: Improved ozone profile retrievals from GOME data with degradation correction in reflectance, Atmos. Chem. Phys., 7, 1575-1583, doi:10.5194/acp7-1575-2007, 2007.

Liu, X., Bhartia, P. K., Chance, K., Spurr, R. J. D., and Kurosu, T. P.: Ozone profile retrievals from the Ozone Monitoring Instrument, Atmos. Chem. Phys., 10, 2521-2537, doi:10.5194/acp-10-25212010, 2010.

Mao, J., Paulot, F., Jacob, D. J., Cohen, R. C., Crounse, J. D., Wennberg, P. O., Keller, C. A., Hudman, R. C., Barkley, M. P., and Horowitz, L. W.: Ozone and organic nitrates over the eastern United States: Sensitivity to isoprene chemistry, J. Geophys. Res.-Atmos., 118, 11256-11268, doi:10.1002/jgrd.50817, 2013.

Marenco, A., Thouret, V., Nedelec, P., Smit, H., Helten, M., Kley, D., Karcher, F., Simon, P., Law, K., Pyle, J., Poschmann, G., Von Wrede, R., Hume, C., and Cook, T.: Measurement of ozone and water vapor by Airbus in-service aircraft: The MOZAIC airborne program, An overview, J. Geophys. Res.-Atmos., 103, 2563125642, doi:10.1029/98jd00977, 1998.

McLinden, C. A., Olsen, S. C., Hannegan, B., Wild, O., Prather, M. J., and Sundet, J.: Stratospheric ozone in 3-D models: A simple chemistry and the cross-tropopause flux, J. Geophys. Res.Atmos., 105, 14653-14665, doi:10.1029/2000jd900124, 2000.

Mollner, A. K., Valluvadasan, S., Feng, L., Sprague, M. K., Okumura, M., Milligan, D. B., Bloss, W. J., Sander, S. P., Martien, P. T., Harley, R. A., McCoy, A. B., and Carter, W. P. L.: Rate of Gas Phase Association of Hydroxyl Radical and Nitrogen Dioxide, Science, 330, 646-649, doi:10.1126/science.1193030, 2010.

Monks, P. S., Archibald, A. T., Colette, A., Cooper, O., Coyle, M., Derwent, R., Fowler, D., Granier, C., Law, K. S., Mills, G. E., Stevenson, D. S., Tarasova, O., Thouret, V., von Schneidemesser, E., Sommariva, R., Wild, O., and Williams, M. L.: Tropospheric ozone and its precursors from the urban to the global scale from 
air quality to short-lived climate forcer, Atmos. Chem. Phys., 15, 8889-8973, doi:10.5194/acp-15-8889-2015, 2015.

Murray, L. T., Jacob, D. J., Logan, J. A., Hudman, R. C., and Koshak, W. J.: Optimized regional and interannual variability of lightning in a global chemical transport model constrained by LIS/OTD satellite data, J. Geophys. Res., 117, D20307, doi:10.1029/2012JD017934, 2012.

Ott, L. E., Pickering, K. E., Stenchikov, G. L., DeCaria, A. J., Lin, R.-F., Wang, D., Lang, S., and Tao, W.-K.: Production of lightning $\mathrm{NO}_{x}$ and its vertical distribution calculated from 3-D cloudscale transport model simulations, J. Geophys. Res., 115, D04301, doi:10.1029/2009JD011880, 2010.

Parrish, D. D., Lamarque, J. F., Naik, V., Horowitz, L., Shindell, D. T., Staehelin, J., Derwent, R., Cooper, O. R., Tanimoto, H., Volz-Thomas, A., Gilge, S., Scheel, H. E., Steinbacher, M., and Froehlich, M.: Long-term changes in lower tropospheric baseline ozone concentrations: Comparing chemistry-climate models and observations at northern midlatitudes, J. Geophys. Res.-Atmos., 119, 5719-5736, doi:10.1002/2013jd021435, 2014.

Prather, M. J., Holmes, C. D., and Hsu, J.: Reactive greenhouse gas scenarios: systematic exploration of uncertainties and the role of atmospheric chemistry, Geophys. Res. Lett., 39, L09803, doi:10.1029/2012GL051440, 2012.

Predoi-Cross, A., Brawley-Tremblay, M., Brown, L. R., Devi, V. M., and Benner, D. C.: Multispectrum analysis of $\left(\mathrm{CH}_{4}\right)$ $\mathrm{C}_{12}$ from 4100 to $4635 \mathrm{~cm}(-1)$ : II. Air-broadening coefficients (widths and shifts), J. Mol. Spectrosc., 236, 201-215, doi:10.1016/j.jms.2006.01.013, 2006.

Price, C. and Rind, D.: A simple lightning parameterization for calculating global lightning distributions, J. Geophys. Res., 97, 9919-9933, 1992.

Prinn, R. G., Huang, J., Weiss, R. F., Cunnold, D. M., Fraser, P. J., Simmonds, P. G., McCulloch, A., Harth, C., Reimann, S., Salameh, P., O’Doherty, S., Wang, R. H. J., Porter, L. W., Miller, B. R., and Krummel, P. B.: Evidence for variability of atmospheric hydroxyl radicals over the past quarter century, Geophys. Res. Lett., 32, L07809, doi:10.1029/2004g1022228, 2005.

Proffitt, M. H. and McLaughlin, R. J.: Fast-response Dualbeam UV Absorption Ozone Photometer Suitable for Use on Stratospheric Balloons, Rev. Sci. Instrum., 54, 1719-1728, doi:10.1063/1.1137316, 1983.

Reidmiller, D. R., Fiore, A. M., Jaffe, D. A., Bergmann, D., Cuvelier, C., Dentener, F. J., Duncan, B. N., Folberth, G., Gauss, M., Gong, S., Hess, P., Jonson, J. E., Keating, T., Lupu, A., Marmer, E., Park, R., Schultz, M. G., Shindell, D. T., Szopa, S., Vivanco, M. G., Wild, O., and Zuber, A.: The influence of foreign vs. North American emissions on surface ozone in the US, Atmos. Chem. Phys., 9, 5027-5042, doi:10.5194/acp-9-5027-2009, 2009.

Rienecker, M. M., Suarez, M. J., Todling, R., Bacmeister, J., Takacs, L., Liu, H.-C., Gu, W., Sienkiewicz, M., Koster, R. D., Gelaro, R., Stajner, I., and Nielsen, J. E.: The GEOS-5 Data Assimilation System - Documentation of Versions 5.0.1, 5.1.0, and 5.2.0, Tech. Rep. Series on Global Modeling and Data Assimilation, 118, NASA Tech. Memo., NASA TM/2008-104606, vol. 27, 2008.

Roelofs, G. J., Kentarchos, A. S., Trickl, T., Stohl, A., Collins, W. J., Crowther, R. A., Hauglustaine, D., Klonecki, A., Law, K. S., Lawrence, M. G., von Kuhlmann, R., and van Weele, M.: Inter- comparison of tropospheric ozone models: Ozone transport in a complex tropopause folding event, J. Geophys. Res., 108, 8529, doi:10.1029/2003JD003462, 2003.

Sillman, S., Logan, J. A., and Wofsy, S. C.: The Sensitivity of Ozone to Nitrogen Oxides and Hydrocarbon in Regional Ozone Episodes, J. Geophys. Res.-Atmos., 95, 1837-1851, doi:10.1029/JD095iD02p01837, 1990.

Simone, N. W., Stettler, M. E. J., and Barrett, S. R. H.: Rapid estimation of global civil aviation emissions with uncertainty quantification, Transport. Res. D-Tr. E., 25, 33-41, doi:10.1016/j.trd.2013.07.001, 2013.

Stevenson, D. S., Dentener, F. J., Schultz, M. G., Ellingsen, K., van Noije, T. P. C., Wild, O., Zeng, G., Amann, M., Atherton, C. S., Bell, N., Bergmann, D. J., Bey, I., Butler, T., Cofala, J., Collins, W. J., Derwent, R. G., Doherty, R. M., Drevet, J., Eskes, H. J., Fiore, A. M., Gauss, M., Hauglustaine, D. A., Horowitz, L. W., Isaksen, I. S. A., Krol, M. C., Lamarque, J. F., Lawrence, M. G., Montanaro, V., Müller, J. F., Pitari, G., Prather, M. J., Pyle, J. A., Rast, S., Rodriguez, J. M., Sanderson, M. G., Savage, N. H., Shindell, D. T., Strahan, S. E., Sudo, K., and Szopa, S.: Multimodel ensemble simulations of present-day and near-future tropospheric ozone, J. Geophys. Res., 111, D08301, doi:10.1029/2005jd006338, 2006.

Streets, D., Bond, T., Carmichael, G., Fernandes, S., Fu, Q., He, D., Klimont, Z., Nelson, S., Tsai, N., and Wang, M. Q.: An inventory of gaseous and primary aerosol emissions in Asia in the year 2000, J. Geophys. Res, 108, 8809, doi:10.1029/2002JD003093, 2003.

Taketani, F., Kanaya, Y., Pochanart, P., Liu, Y., Li, J., Okuzawa, K., Kawamura, K., Wang, Z., and Akimoto, H.: Measurement of overall uptake coefficients for $\mathrm{HO} 2$ radicals by aerosol particles sampled from ambient air at Mts. Tai and Mang (China), Atmos. Chem. Phys., 12, 11907-11916, doi:10.5194/acp-1211907-2012, 2012.

Terrenoire, E., Bessagnet, B., Rouïl, L., Tognet, F., Pirovano, G., Létinois, L., Beauchamp, M., Colette, A., Thunis, P., Amann, M., and Menut, L.: High-resolution air quality simulation over Europe with the chemistry transport model CHIMERE, Geosci. Model Dev., 8, 21-42, doi:10.5194/gmd-8-21-2015, 2015.

Thornton, J. A., Jaegle, L., and McNeill, V. F.: Assessing known pathways for $\mathrm{HO}_{2}$ loss in aqueous atmospheric aerosols: Regional and global impacts on tropospheric oxidants, J. Geophys. Res.-Atmos., 113, D05303, doi:10.1029/2007jd009236, 2008.

Thouret, V., Marenco, A., Logan, J. A., Nedelec, P., and Grouhel, C.: Comparisons of ozone measurements from the MOZAIC airborne program and the ozone sounding network at eight locations, J. Geophys. Res.-Atmos., 103, 25695-25720, doi:10.1029/98jd02243, 1998.

Valin, L. C., Russell, A. R., Hudman, R. C., and Cohen, R. C.: Effects of model resolution on the interpretation of satellite $\mathrm{NO}_{2}$ observations, Atmos. Chem. Phys., 11, 11647-11655, doi:10.5194/acp-11-11647-2011, 2011.

van der Werf, G. R., Randerson, J. T., Giglio, L., Collatz, G. J., Mu, M., Kasibhatla, P. S., Morton, D. C., DeFries, R. S., Jin, Y., and van Leeuwen, T. T.: Global fire emissions and the contribution of deforestation, savanna, forest, agricultural, and peat fires (19972009), Atmos. Chem. Phys., 10, 11707-11735, doi:10.5194/acp10-11707-2010, 2010. 
Vinken, G. C. M., Boersma, K. F., van Donkelaar, A., and Zhang, L.: Constraints on ship $\mathrm{NO}_{x}$ emissions in Europe using GEOSChem and $\mathrm{OMI}$ satellite $\mathrm{NO}_{2}$ observations, Atmos. Chem. Phys., 14, 1353-1369, doi:10.5194/acp-14-1353-2014, 2014.

Wang, Y., Zhang, Y., Hao, J., and Luo, M.: Seasonal and spatial variability of surface ozone over China: contributions from background and domestic pollution, Atmos. Chem. Phys., 11, 35113525, doi:10.5194/acp-11-3511-2011, 2011.

Weaver, C. P., Liang, X. Z., Zhu, J., Adams, P. J., Amar, P., Avise, J., Caughey, M., Chen, J., Cohen, R. C., Cooter, E., Dawson, J. P., Gilliam, R., Gilliland, A., Goldstein, A. H., Grambsch, A., Grano, D., Guenther, A., Gustafson, W. I., Harley, R. A., He, S., Hemming, B., Hogrefe, C., Huang, H. C., Hunt, S. W., Jacob, D. J., Kinney, P. L., Kunkel, K., Lamarque, J. F., Lamb, B., Larkin, N. K., Leung, L. R., Liao, K. J., Lin, J. T., Lynn, B. H., Manomaiphiboon, K., Mass, C., McKenzie, D., Mickley, L. J., O'Neill, S. M., Nolte, C., Pandis, S. N., Racherla, P. N., Rosenzweig, C., Russell, A. G., Salathe, E., Steiner, A. L., Tagaris, E., Tao, Z., Tonse, S., Wiedinmyer, C., Williams, A., Winner, D. A., Woo, J. H., Wu, S., and Wuebbles, D. J.: A preliminary synthesis of modeled climate change impacts on us regional ozone concentrations, B. Am. Meteorol. Soc., 90, 18431863, doi:10.1175/2009bams2568.1, 2009.

Wild, O. and Prather, M. J.: Global tropospheric ozone modeling: Quantifying errors due to grid resolution, J. Geophys. Res., 111, D11305, doi:10.1029/2005jd006605, 2006.

Wofsy, S. C.: HIAPER Pole-to-Pole Observations (HIPPO): finegrained, global-scale measurements of climatically important atmospheric gases and aerosols, Philos. T. Roy. Soc. A, 369, 20732086, doi:10.1098/rsta.2010.0313, 2011.

Wu, S., Mickley, L. J., Jacob, D. J., Logan, J. A., Yantosca, R. M., and Rind, D.: Why are there large differences between models in global budgets of tropospheric ozone?, J. Geophys. Res.-Atmos., 112, D05302, doi:10.1029/2006jd007801, 2007.

Xiao, Y., Logan, J. A., Jacob, D. J., Hudman, R. C., Yantosca, R., and Blake, D. R.: The global budget of ethane and regional constraints on US sources, J. Geophys. Res., 113, D21306, doi:10.1029/2007JD009415, 2008.

Yan, Y.-Y., Lin, J.-T., Kuang, Y., Yang, D., and Zhang, L.: Tropospheric carbon monoxide over the Pacific during HIPPO: two-way coupled simulation of GEOS-Chem and its multiple nested models, Atmos. Chem. Phys., 14, 12649-12663, doi:10.5194/acp-14-12649-2014, 2014.
Young, P. J., Archibald, A. T., Bowman, K. W., Lamarque, J.-F., Naik, V., Stevenson, D. S., Tilmes, S., Voulgarakis, A., Wild, O., Bergmann, D., Cameron-Smith, P., Cionni, I., Collins, W. J., Dalsøren, S. B., Doherty, R. M., Eyring, V., Faluvegi, G., Horowitz, L. W., Josse, B., Lee, Y. H., MacKenzie, I. A., Nagashima, T., Plummer, D. A., Righi, M., Rumbold, S. T., Skeie, R. B., Shindell, D. T., Strode, S. A., Sudo, K., Szopa, S., and Zeng, G.: Preindustrial to end 21 st century projections of tropospheric ozone from the Atmospheric Chemistry and Climate Model Intercomparison Project (ACCMIP), Atmos. Chem. Phys., 13, 2063 2090, doi:10.5194/acp-13-2063-2013, 2013.

Zbinden, R. M., Thouret, V., Ricaud, P., Carminati, F., Cammas, J.P., and Nédélec, P.: Climatology of pure tropospheric profiles and column contents of ozone and carbon monoxide using MOZAIC in the mid-northern latitudes $\left(24^{\circ} \mathrm{N}\right.$ to $\left.50^{\circ} \mathrm{N}\right)$ from 1994 to 2009, Atmos. Chem. Phys., 13, 12363-12388, doi:10.5194/acp13-12363-2013, 2013.

Zhang, L., Jacob, D. J., Downey, N. V., Wood, D. A., Blewitt, D., Carouge, C. C., van Donkelaar, A., Jones, D. B. A., Murray, L. T., and Wang, Y.: Improved estimate of the policy-relevant background ozone in the United States using the GEOS-Chem global model with $1 / 2^{\circ} \times 2 / 3^{\circ}$ horizontal resolution over North America, Atmos. Environ., 45, 6769-6776, doi:10.1016/j.atmosenv.2011.07.054, 2011.

Zhang, L., Jacob, D. J., Yue, X., Downey, N. V., Wood, D. A., and Blewitt, D.: Sources contributing to background surface ozone in the US Intermountain West, Atmos. Chem. Phys., 14, 52955309, doi:10.5194/acp-14-5295-2014, 2014.

Zhang, Q., Streets, D. G., Carmichael, G. R., He, K. B., Huo, H., Kannari, A., Klimont, Z., Park, I. S., Reddy, S., Fu, J. S., Chen, D., Duan, L., Lei, Y., Wang, L. T., and Yao, Z. L.: Asian emissions in 2006 for the NASA INTEX-B mission, Atmos. Chem. Phys., 9, 5131-5153, doi:10.5194/acp-9-5131-2009, 2009.

Ziemke, J. R., Chandra, S., Labow, G. J., Bhartia, P. K., Froidevaux, L., and Witte, J. C.: A global climatology of tropospheric and stratospheric ozone derived from Aura OMI and MLS measurements, Atmos. Chem. Phys., 11, 9237-9251, doi:10.5194/acp11-9237-2011, 2011. 